\title{
Hydrogeochemical characterization and assessment of water suitability for drinking and irrigation in crystalline rocks of Mothkur region, Telangana State, South India
}

\author{
G. Sakram ${ }^{1} \cdot$ Narsimha Adimalla ${ }^{2,3}$
}

Received: 30 October 2016 / Accepted: 3 August 2018 / Published online: 14 August 2018

(c) The Author(s) 2018

\begin{abstract}
The present study confers the chemical quality of groundwater and surface water of Mothkur region, Telangana State, for drinking and irrigational purposes. Mothkur region is geologically occupied by the Archaean crystalline terrain. Most of the population depends on groundwater for their daily needs especially for drinking, house needs and irrigation purposes. For this reason, twenty-five groundwater and five surface water samples were collected and analysed for $\mathrm{pH}$, electrical conductivity, total dissolved solids (TDS), total hardness (TH) bicarbonate $\left(\mathrm{HCO}_{3}^{-}\right)$, chloride $\left(\mathrm{Cl}^{-}\right)$, sulphate $\left(\mathrm{SO}_{4}{ }^{2-}\right)$, fluoride $\left(\mathrm{F}^{-}\right)$, calcium $\left(\mathrm{Ca}^{2+}\right)$, magnesium $\left(\mathrm{Mg}^{2+}\right)$, sodium $\left(\mathrm{Na}^{+}\right)$and potassium $\left(\mathrm{K}^{+}\right)$. The results are evaluated and compared with WHO and BIS water quality standards. Based on obtained results 32\%,20\%, 28\% and $4 \%$ of groundwater samples are not recommended for drinking with reference to the concentrations of fluoride, TDS, TH and $\mathrm{Cl}^{-}$, respectively. Base-exchange indices and meteoric genesis indices classified $67 \%$ and $33 \%$ of the water sources as the $\mathrm{Na}^{+}-\mathrm{HCO}_{3}{ }^{-}$type and deep meteoric water percolation type, respectively. Piper trilinear diagram for geochemical classification indicates $44 \%$ and $60 \%$ of groundwater and surface water samples of $\mathrm{Ca}^{2+}-\mathrm{Na}^{+}-\mathrm{HCO}_{3}{ }^{-}$type and $29 \%$ belong to $\mathrm{Na}^{+}-\mathrm{HCO}_{3}{ }^{-}$types. Multivariate graphical methods have been carried out using the United States Salinity Laboratory diagram, Wilcox diagram, sodium adsorption ratio, per cent sodium $(\% \mathrm{Na})$, residual sodium carbonate and permeability index which indicate that majority of groundwater samples are useful for irrigation purposes.
\end{abstract}

Keywords Hydrochemistry · Groundwater quality $\cdot$ Sodium adsorption ratio (SAR) $\cdot$ Per cent sodium $(\% \mathrm{Na}) \cdot$ Residual sodium carbonate (RSC) · Permeability index (PI) · Mothkur region · South India

\section{Introduction}

Electronic supplementary material The online version of this article (https://doi.org/10.1007/s13201-018-0787-6) contains supplementary material, which is available to authorized users.

Narsimha Adimalla

adimallanarsimha@gmail.com

1 Department of Applied Geochemistry, University College of Science, Osmania University, Hyderabad 500007 , Telangana State, India

2 School of Environmental Science and Engineering, Chang'an University, No. 126 Yanta Road, Xi'an 710054, Shaanxi, China

3 Key Laboratory of Subsurface Hydrology and Ecological Effects in Arid Region of the Ministry of Education, Chang' an University, No. 126 Yanta Road, Xi' an 710054, Shaanxi, China
In recent times, huge population growth, intense urbanization, increasing industries and tremendous agricultural activities all over the world have contributed to tremendous increase in demand for freshwater for household applications, agricultural and industries (Adimalla and Venkatayogi 2018; Alexakis and Tsakiris 2010). Due to insufficient supply of surface water, most of the people in arid and semiarid regions in India are depending primarily on groundwater for their daily needs and irrigation usages. Moreover, groundwater today accounts for a whopping $62.4 \%$ of net irrigation needs, $85 \%$ of rural drinking water needs and $50 \%$ of urban water needs (Raju 1998). He et al. (2015) have estimated that more than 1.5 billion people worldwide rely on groundwater as their chief source of drinking water. Hence, it is concluded that the groundwater is an elixir of life and other hand groundwater resource is facing more problems in 
recent years including quality aspects especially in arid and semiarid regions. Specifically, agricultural chemicals, such as, fertilizers, pesticides and other metal pollution, make the water unfit for drinking purposes (Kelly 1997). Therefore, knowledge of hydrogeochemistry of water is very essential to evaluate the water for drinking, irrigation and other needs. Eventually, the quality of groundwater is controlled by many factors such as rainfall, topographic relief, mineral dissolution, mineral solubility, ion exchange, oxidation, reduction, natural and anthropogenic activities such as geological structure and mineralogy of the watersheds and aquifers, the residence time, poor sanitary conditions, application of fertilizers and pesticides for higher crop yields without understanding the chemical characteristics of soils and industrial development without following any appropriate remedial measures (Todd 1980; Appelo and Postma 2005; Drever 1997; Wang et al. 2015; Hajizadeh Namaghi et al. 2011; Sappa et al. 2015). Therefore, it is most essential to monitor the quality of water resources in arid and semiarid regions in India particularly groundwater, which is considered as a principal source for drinking and irrigation purposes.

There are number of studies that have been conducted on groundwater quality assessment in many parts of the arid and semiarid regions. Kaur et al. (2016) have studied the groundwater quality for drinking and irrigation purposes in Malwa region, Punjab. Subramani et al. (2005) have studied groundwater quality and its suitability for drinking and agricultural use in Tamil Nadu. Tamma et al. (2015) have studied hydrochemical assessment of groundwater in Jalandhar district. Thakur et al. (2016) have studied that assessment of groundwater for drinking and agriculture in parts of Punjab. Ravikumar et al. (2012) have studied geochemistry of groundwater quality and its evaluation in Karnataka. Narsimha and Sudarshan (2017a) have studied contamination of fluoride in groundwater in Siddipet and reported high fluoride concentration in southern part of Siddipet, Medak district. Amiri et al. (2015) have reported that groundwater chemistry and its suitability for drinking and agricultural purpose in central Iran. Moreover, in India and many parts of the world, abundant studies have been carried out to assess the geochemical characteristics of groundwater quality with respect of drinking and irrigation (Kudoda and Abdalla 2015; Adimalla et al. 2018a; Murkute 2014; Raju et al. 2011; Dimitris Alexakis 2011; Subba Rao et al. 2012; Sudarshan et al. 2014; Li et al. 2017a, b; Jeevanandam et al. 2006; Li et al. 2012; 2014a, b; Cheng Qian et al. 2016; Sappa et al. 2015; Narsimha and Sudarshan 2013; Salem et al. 2015; Sethy et al. 2016; He et al. 2015; Panaskar et al. 2016). Furthermore, a number of researchers have used electrical conductivity (EC), sodium absorption ratio (SAR), per cent sodium (\%Na), residual sodium carbonate (RSC) and permeability index (PI) classifications for irrigation water quality in many parts of the country (Adimalla and Venkatayogi 2018; Adimalla et al. 2018a; Qian et al. 2016; Sappa et al. 2015; Narsimha et al. 2013a, b; Aghazadeh and Mogaddam 2011; Ravikumar et al. 2012; Li et al. 2012). Eventually, Nalgonda district represents a true picture of hard terrain, where there is no sufficient surface water; therefore, most of the district people depend on groundwater for their daily needs. Mothkur region is one of the mandal in Nalgonda district, where people rely on groundwater and observed tremendous increase day by day and with number of water quality issues in various places in this region. This is one of the main reasons to select Mothkur region to evaluate the groundwater and surface water quality issues with main objective to assess the groundwater and surface water quality for drinking and irrigation purposes.

\section{Geology of the study region}

The studied area is situated in the northern part of Nalgonda district, Telangana State, South India (Fig. 1) and lies between $17.4147 \mathrm{~N}$ and $17.4542 \mathrm{~N}$ latitude and $79.1130 \mathrm{E}$ and 79.1561E longitude in Survey of India Toposheet No. 56 O3. The entire Mothkur region is under Archaean crystalline rocks, comparing granites, gneisses, schists and intrusive. The crystalline rocks inherently devoid of primary porosity; however, subsequently, with dynamic process of weathering, the rocks undergo fracturing and fissuring and joints over a period of time, leading to the development of secondary porosity, which forms the source for groundwater. July is the wettest month of the year contributing about $23 \%$ of annual rainfall. The mean seasonal rainfall is $562 \mathrm{~mm}$ in south-west monsoon (June-September), $139 \mathrm{~mm}$ in north-east monsoon (October-December), $7 \mathrm{~mm}$ rainfall in winter (January-February) and $43 \mathrm{~mm}$ in summer (March-May). About 74.8\% of the annual rain fall is received from south-west monsoon period during June-September and $18.5 \%$ rainfall contributes from north-east monsoon.

\section{Materials and methods}

Twenty-five groundwater and five surface water samples were collected in and around Mothkur region (Fig. 1), Nalgonda district, Telangana, in one-litre polyethylene bottles and stored at $10{ }^{\circ} \mathrm{C}$. All containers used for sampling were washed with $10 \%$ nitric acid solution followed by double distilled water. Immediately after sampling, $\mathrm{pH}$ and electrical conductivity (EC) were measured in the field with using pH/EC/TDS meter (Hanna HI9811-5). Total dissolved solids (TDS) were calculated from EC multiplied by 0.64 (Brown et al. 1970; Hem 1985). Total hardness (TH) bicarbonate $\left(\mathrm{HCO}_{3}{ }^{-}\right)$, chloride $\left(\mathrm{Cl}^{-}\right)$, sulphate $\left(\mathrm{SO}_{4}{ }^{2-}\right)$, fluoride $\left(\mathrm{F}^{-}\right)$, 

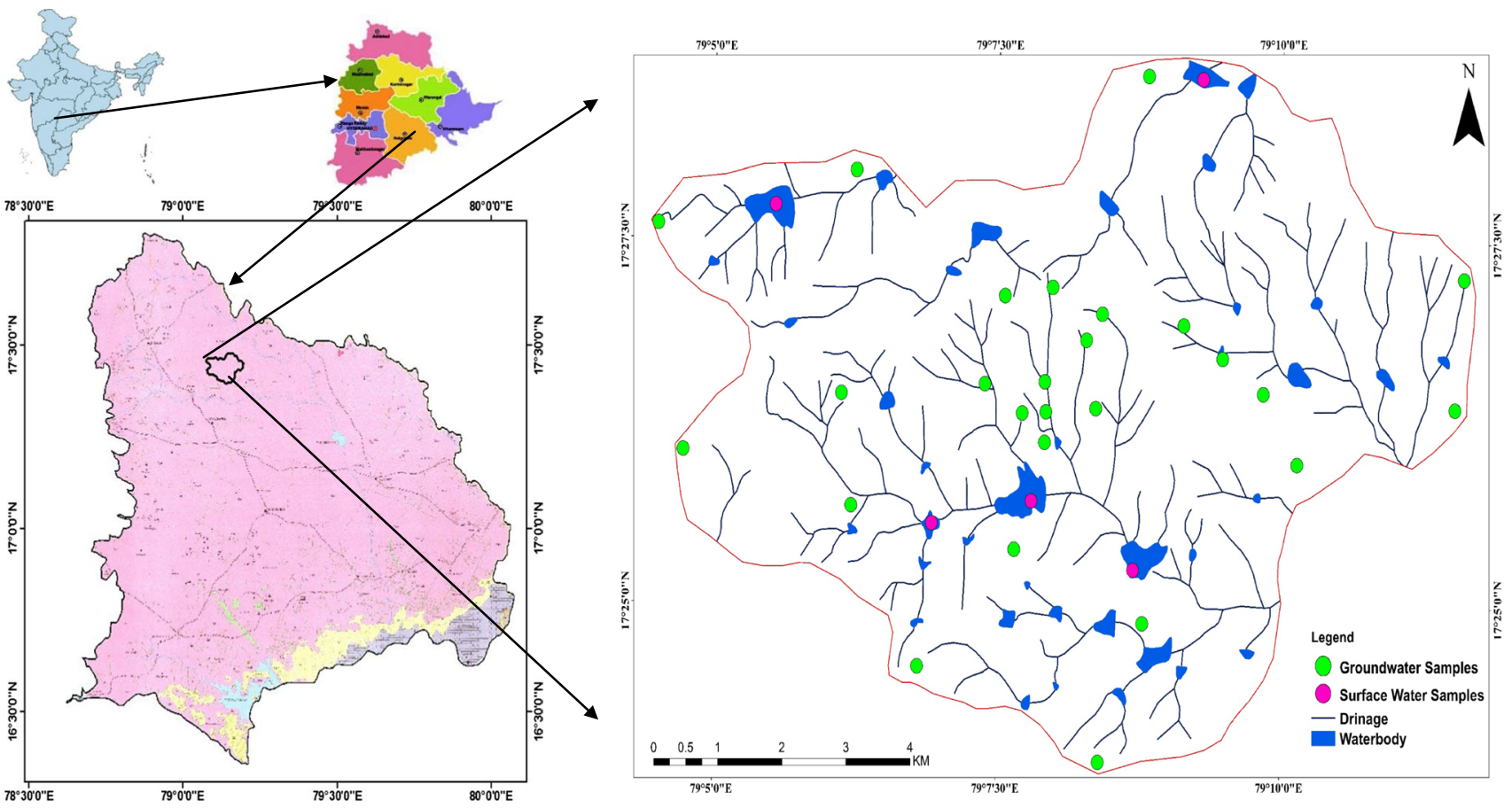

Fig. 1 Groundwater and surface water sampling locations along with drainage map of the Mothkur region, Telangana State, South India

calcium $\left(\mathrm{Ca}^{2+}\right)$, magnesium $\left(\mathrm{Mg}^{2+}\right)$, sodium $\left(\mathrm{Na}^{+}\right)$and potassium $\left(\mathrm{K}^{+}\right)$were analysed with using standard methods (APHA 1995), and detailed procedure is presented in Table 1. Analysed water samples precision expressed as per cent relative standard deviation was below $10 \%$, which is within the acceptable limit (Domenico and Schwartz 1990). Moreover, sodium absorption ratio (SAR), percentage sodium $(\% \mathrm{Na})$, residual sodium carbonate (RSC) and permeability index (PI) classifications were used for irrigation water quality and calculation methods are presented in Table 1.

\section{Preparation of spatial distribution maps}

The base map of the study area was prepared using Survey of India topographic sheet $56 \mathrm{O} 3$ and digitized using ArcGIS10.1 software (Fig. 1). The precise locations of sampling points were marked by using GPS (Garman eTrex 30), and the exact longitudes and latitudes of sampling points were imported in GIS platform for further analysis. Spatial analyst tools extension used to interpolate the inverse distance weighed (IDW) algorithm was an effective tool to prepare the spatial distribution maps of the chemical parameters of water of the study area. The IDW technique has been used widely in global scale to generate the spatial distribution maps for various purposes, especially, identify the high, medium and low chemical elements concentration zones.

\section{Result and discussion}

In order to give the general picture of the surface water and groundwater, analytical results are presented in Tables 2 and 3 . The $\mathrm{pH}$ values of surface water and groundwater of the study area varied from 7.2 to 7.8 and 7.0 to 8.4 , respectively, indicating marginally alkaline nature (Tables 2,3 ). The obtained electrical conductivity (EC) values of surface water and groundwater samples varied were ranged from 908 to $2860 \mu \mathrm{S} / \mathrm{cm}$ and 676 to $4016 \mu \mathrm{S} / \mathrm{cm}$ at $25^{\circ} \mathrm{C}$, respectively (Tables 2, 3). Concentration of total dissolved solids (TDS) in surface water and groundwater ranged from 595 to $1887 \mathrm{mg} / \mathrm{L}$ and 446 to $2650 \mathrm{mg} / \mathrm{L}$, respectively (Tables 2, 3). However, Freeze and Cherry (1979) categorized water on the basis of TDS concentration into four groups which are represented as fresh (TDS $<1000 \mathrm{mg} / \mathrm{L})$, brackish $(>1000 \mathrm{mg} / \mathrm{L})$, saline $(>10,000 \mathrm{mg} / \mathrm{L})$ and brine $(100,000 \mathrm{mg} / \mathrm{L})$. Based on this classification, surface water and groundwater fall in fresh category in about 4 and 17 samples only and remaining are in brackish category (Fetter 1990; Table 4). The TH in surface water and groundwater ranges from 285 to $870 \mathrm{mg} / \mathrm{L}$ and 280 to $1185 \mathrm{mg} / \mathrm{L}$, respectively (Tables 2, 3). The TH classification according to Sawyer and McCarty (1967) is clearly illustrated in Table 5, and based on this most of the surface and groundwater samples fall in very hard category, which is not useful for drinking purposes (Table 5). 
Table 1 Instrumental, titrimetric and calculation methods used for chemical analysis of water samples in Mothkur region, Telangana State

\begin{tabular}{|c|c|c|c|c|c|}
\hline Parameters & Characteristics & Analytical method & Reagents & Unit & References \\
\hline \multirow[t]{4}{*}{ General } & $\mathrm{pH}$ & $\mathrm{pH} / \mathrm{EC} / \mathrm{TDS}$ meter & $\mathrm{pH} 4,7$ and 9.2 & - & APHA (1995) \\
\hline & Electrical Conductivity & $\mathrm{pH} / \mathrm{EC} / \mathrm{TDS}$ meter & Potassium chloride & $\mu \mathrm{S} / \mathrm{cm}$ & APHA (1995) \\
\hline & Total dissolved solids (TDS) & Calculation & EC X $(0.55-0.75)$ & $\mathrm{mg} / \mathrm{L}$ & Hem (1991) \\
\hline & Total hardness (as $\mathrm{CaCO}_{3}$ ) & EDTA titrimetric & $\begin{array}{l}\text { EDTA, ammonia buffer and } \\
\text { Eriochrome Black-T (EBT) } \\
\text { indicator }\end{array}$ & $\mathrm{mg} / \mathrm{L}$ & APHA (1995) \\
\hline \multirow[t]{4}{*}{ Major Cations } & Calcium (as $\mathrm{Ca}^{2+}$ ) & EDTA titrimetric & $\begin{array}{l}\text { EDTA, sodium hydroxide and } \\
\text { murexide }\end{array}$ & $\mathrm{mg} / \mathrm{L}$ & APHA (1995) \\
\hline & Magnesium (as $\mathrm{Mg}^{2+}$ ) & Calculation & $\begin{array}{l}\mathrm{MgH}=\mathrm{TH}-\mathrm{CaH} ; \mathrm{Mg}=\mathrm{MgH} \\
\text { X Eq.Wt of } \mathrm{Mg} \text { X normality } \\
\text { of EDTA }\end{array}$ & $\mathrm{mg} / \mathrm{L}$ & APHA (1995) \\
\hline & Sodium $\left(\right.$ as $\left.\mathrm{Na}^{+}\right)$ & Flame photometric & $\begin{array}{l}\text { Sodium chloride }(\mathrm{NaCl}) \text { and } \\
\mathrm{KCl}\end{array}$ & $\mathrm{mg} / \mathrm{L}$ & APHA (1995) \\
\hline & Potassium (as $\mathrm{K}^{+}$) & Flame photometric & $\mathrm{NaCl}$ and $\mathrm{KCl}$ & $\mathrm{mg} / \mathrm{L}$ & APHA (1995) \\
\hline \multirow[t]{4}{*}{ Major anions } & Bicarbonates $\left(\mathrm{HCO}_{3}^{-}\right)$ & Titrimetric & $\begin{array}{l}\text { Hydrosulphuric acid }\left(\mathrm{H}_{2} \mathrm{SO}_{4}\right) \text {, } \\
\text { phenolphthalein and methyl } \\
\text { orange }\end{array}$ & $\mathrm{mg} / \mathrm{L}$ & APHA (1995) \\
\hline & Chloride $\left(\mathrm{Cl}^{-}\right)$ & Titrimetric & $\begin{array}{l}\text { Silver nitrate }\left(\mathrm{AgNO}_{3}^{\prime} \text {, potas- }\right. \\
\text { sium chromate }\end{array}$ & $\mathrm{mg} / \mathrm{L}$ & APHA (1995) \\
\hline & Fluoride $\left(\mathrm{F}^{-}\right)$ & $\begin{array}{l}\text { ISE (ion selective electrode; } \\
\text { Thermo Orion) }\end{array}$ & TISAB III and NaF & $\mathrm{mg} / \mathrm{L}$ & APHA (1995) \\
\hline & Sulphates $\left(\mathrm{SO}_{4}{ }^{2-}\right)$ & UV-visible spectrophotometer & $\begin{array}{l}\mathrm{HCl} \text {, ethyl alcohol, } \mathrm{NaCl}, \\
\text { barium chloride, sodium } \\
\text { sulphate }\end{array}$ & $\mathrm{mg} / \mathrm{L}$ & APHA (1995) \\
\hline \multirow[t]{6}{*}{ Irrigation water } & Sodium absorption ratio (SAR) & $\frac{\mathrm{Na}^{+}}{\sqrt{\left(\mathrm{Ca}^{2+}+\mathrm{Mg}^{2+}\right) / 2}}$ & - & $\mathrm{meq} / \mathrm{L}$ & Richards (1954) \\
\hline & $\begin{array}{l}\text { Residual sodium carbonate } \\
\text { (RSC) }\end{array}$ & $\left(\mathrm{CO}_{3}^{-}+\mathrm{HCO}_{3}^{-}\right)-\left(\mathrm{Ca}^{2+}+\mathrm{Mg}^{2+}\right)$ & - & meq/L & Eaton (1950) \\
\hline & Per cent sodium (\%Na) & $\frac{\mathrm{Na}^{+}+\mathrm{K}^{+}}{\left(\mathrm{Ca}^{2+}+\mathrm{Mg}^{2+}+\mathrm{Na}^{+}+\mathrm{K}^{+}\right)} \times 100$ & - & $\%$ & Wilcox (1955) \\
\hline & Base-exchange indices (BEI) & {$\left[\mathrm{Na}^{+}-\mathrm{Cl}^{-} / \mathrm{SO}_{4}^{2-}\right.$} & - & $\mathrm{meq} / \mathrm{L}$ & Matthess (1982) \\
\hline & Meteoric genesis indices (MGI) & {$\left[\left(\mathrm{Na}^{+}+\mathrm{K}^{+}\right)-\mathrm{Cl}^{-}\right] / \mathrm{SO}_{4}{ }^{2-}$} & - & $\mathrm{meq} / \mathrm{L}$ & Matthess (1982) \\
\hline & Permeability index (PI) & $\mathrm{PI}=\frac{\mathrm{Na}^{+}+\sqrt{\mathrm{HCO}_{3}}}{\left(\mathrm{Ca}^{2+}+\mathrm{Mg}^{2+}+\mathrm{Na}^{+}\right)} \times 100$ & - & meq/L & Doneen (1964) \\
\hline
\end{tabular}

\section{Cation and anion chemistry}

The major ions like calcium, magnesium, sodium, potassium, bicarbonate, sulphate, nitrate and chloride are present in most of the water having $>1 \mathrm{mg} / \mathrm{L}$ (Younger 2007). The major cations according to their decreasing concentration expressed in $\mathrm{mg} / \mathrm{L}$ are as follows: $\mathrm{Na}^{+}>\mathrm{Ca}^{2+}>\mathrm{Mg}^{2+}>\mathrm{K}^{+}$. Sodium is the most profuse alkali metal. The analytical data reveals that the concentration of $\mathrm{Na}^{+}$in surface water and groundwater samples range between 131 and $400 \mathrm{mg} / \mathrm{L}$ and 129 and $545 \mathrm{mg} / \mathrm{L}$ with an average of 193.6 and $214.8 \mathrm{mg} / \mathrm{L}$, respectively (Tables 2,3). The maximum allowable limit for $\mathrm{Na}^{+}$is $200 \mathrm{mg} / \mathrm{L}$ (WHO 1997; BIS 2003). Twelve (BH-1 to BH-5, BH-8, BH-16 to BH-18, BH-21 and BH-25) groundwater samples and one (SW-2) surface water sample have $\mathrm{Na}^{+}$concentration above the permissible limit (Tables 2, 3 ). However, the intake of high levels of $\mathrm{Na}^{+}$in groundwater may cause hypertension, arteriosclerosis, circulatory diseases, renal, oedema and kidney problems ( $\mathrm{Li}$ et al. 2017a, b; Srinivas et al. 2013). The analytical results show that the $\mathrm{Ca}^{2+}$ in surface water and groundwater samples varied from 56 to $92 \mathrm{mg} / \mathrm{L}$ and 24 to $242 \mathrm{mg} / \mathrm{L}$ was on average $72.6 \mathrm{mg} / \mathrm{L}$ and $77.2 \mathrm{mg} / \mathrm{L}$, respectively (Tables 2,3 ). The maximum admissible limit for $\mathrm{Ca}^{2+}$ is $200 \mathrm{mg} / \mathrm{L}$, and all collected samples are well within the maximum tolerable limits except one location as prescribed by WHO (1997) and BIS (2003) (Table 3). Surface water and groundwater samples concentration of $\mathrm{K}^{+}$varies from 1 to $4 \mathrm{mg} / \mathrm{L}$ and 2 to $6 \mathrm{mg} / \mathrm{L}$, respectively (Tables 2, 3). Moreover, $\mathrm{K}^{+}$is an essential nutrient but if ingested in excess may behave as a laxative (Alam et al. 2012). 100\% of surface water and groundwater samples are within the recommended limit of $12 \mathrm{mg} / \mathrm{L}$ prescribed by WHO (1997) (Table 3). Furthermore, the $\mathrm{Mg}^{2+}$ concentration in surface water and groundwater ranges from 25 to $56 \mathrm{mg} / \mathrm{L}$ and 15 to $176 \mathrm{mg} / \mathrm{L}$, with a mean value of 38.8 and $42.6 \mathrm{mg} / \mathrm{L}$, respectively (Tables 2 , 
Table 2 Hydrogeochemical characteristics of groundwater $(\mathrm{BH})$ and surface water $(\mathrm{SW})$ of the Mothkur region, Telangana State, South India

\begin{tabular}{|c|c|c|c|c|c|c|c|c|c|c|c|c|}
\hline Field label & $\mathrm{Ca}^{2+}$ & $\mathrm{Mg}^{2+}$ & $\mathrm{Na}^{+}$ & $\mathrm{K}^{+}$ & $\mathrm{HCO}_{3}^{-}$ & $\mathrm{SO}_{4}{ }^{2-}$ & $\mathrm{Cl}^{-}$ & $\mathrm{F}^{-}$ & $\mathrm{pH}$ & $\mathrm{EC}$ & TDS & TH \\
\hline SW-1 & 56 & 35 & 131 & 1 & 470 & 80 & 220 & 0.68 & 7.8 & 1460 & 964 & 285 \\
\hline SW-2 & 92 & 56 & 400 & 4 & 360 & 140 & 545 & 0.63 & 7.6 & 2860 & 1887 & 870 \\
\hline SW-3 & 68 & 35 & 145 & 2 & 439 & 76 & 205 & 0.69 & 7.2 & 1449 & 956 & 315 \\
\hline SW-4 & 60 & 43 & 149 & 2 & 433 & 125 & 215 & 0.63 & 7.5 & 1481 & 977 & 325 \\
\hline SW-5 & 82 & 25 & 143 & 2 & 408 & 27 & 40 & 0.81 & 7.5 & 902 & 595 & 310 \\
\hline BH-1 & 148 & 90 & 264 & 3 & 488 & 190 & 530 & 1.85 & 8.4 & 3000 & 1980 & 575 \\
\hline $\mathrm{BH}-2$ & 41 & 24 & 267 & 3 & 457 & 80 & 315 & 1.13 & 8.3 & 1800 & 1188 & 580 \\
\hline BH-3 & 42 & 26 & 212 & 3 & 317 & 118 & 185 & 0.86 & 7.3 & 1384 & 913 & 460 \\
\hline BH-4 & 46 & 28 & 276 & 2 & 329 & 80 & 315 & 1.02 & 7.3 & 1870 & 1234 & 600 \\
\hline BH-5 & 38 & 23 & 205 & 2 & 311 & 117 & 340 & 0.97 & 7.2 & 1235 & 815 & 445 \\
\hline BH-6 & 38 & 23 & 184 & 2 & 348 & 140 & 120 & 1.09 & 7.4 & 1089 & 719 & 400 \\
\hline BH-7 & 38 & 23 & 166 & 2 & 366 & 51 & 80 & 1.14 & 7.3 & 970 & 640 & 360 \\
\hline BH-8 & 38 & 23 & 207 & 2 & 439 & 80 & 115 & 1.15 & 7.3 & 1183 & 781 & 450 \\
\hline BH-9 & 44 & 27 & 159 & 2 & 432 & 35 & 60 & 1.49 & 7.6 & 933 & 615 & 345 \\
\hline BH-10 & 36 & 22 & 170 & 2 & 360 & 55 & 70 & 0.98 & 7.4 & 960 & 633 & 370 \\
\hline BH-11 & 34 & 21 & 173 & 2 & 396 & 58 & 75 & 0.99 & 7.6 & 1004 & 663 & 375 \\
\hline BH-12 & 24 & 15 & 156 & 2 & 378 & 46 & 65 & 0.84 & 7.3 & 926 & 611 & 340 \\
\hline BH-13 & 48 & 29 & 159 & 2 & 512 & 45 & 65 & 1.55 & 7.3 & 1052 & 694 & 345 \\
\hline BH-14 & 242 & 67 & 405 & 5 & 402 & 75 & 430 & 0.84 & 7 & 2650 & 1749 & 880 \\
\hline BH-15 & 82 & 30 & 152 & 2 & 299 & 32 & 50 & 1.03 & 7.2 & 731 & 548 & 330 \\
\hline BH-16 & 184 & 176 & 545 & 6 & 628 & 240 & 785 & 1.64 & 8.1 & 4016 & 2650 & 1185 \\
\hline ВН-17 & 90 & 85 & 266 & 3 & 463 & 55 & 475 & 1.77 & 7.8 & 2335 & 1541 & 575 \\
\hline BH-18 & 88 & 72 & 228 & 3 & 543 & 75 & 415 & 1.62 & 7.4 & 2680 & 1768 & 495 \\
\hline BH-19 & 82 & 26 & 143 & 2 & 402 & 25 & 25 & 1.1 & 7.3 & 838 & 553 & 310 \\
\hline BH-20 & 80 & 24 & 138 & 2 & 409 & 18 & 340 & 1.04 & 7.5 & 820 & 541 & 300 \\
\hline BH-21 & 140 & 80 & 272 & 3 & 348 & 52 & 360 & 1.78 & 7.8 & 2160 & 1425 & 680 \\
\hline BH-22 & 64 & 40 & 147 & 2 & 457 & 19 & 35 & 1.29 & 7.5 & 881 & 581 & 320 \\
\hline BH-23 & 82 & 18 & 129 & 2 & 433 & 24 & 10 & 0.96 & 7.2 & 676 & 446 & 280 \\
\hline BH-24 & 78 & 29 & 145 & 2 & 366 & 20 & 45 & 1.15 & 7.5 & 890 & 587 & 315 \\
\hline BH-25 & 104 & 44 & 202 & 3 & 329 & 27 & 145 & 1.11 & 7.4 & 1160 & 765 & 440 \\
\hline
\end{tabular}

$\mathrm{Ca}^{2+}, \mathrm{Mg}^{2+}, \mathrm{Na}^{+}, \mathrm{K}^{+}, \mathrm{HCO}_{3}{ }^{-}, \mathrm{SO}_{4}{ }^{2-}, \mathrm{Cl}^{-}, \mathrm{F}^{-}$, TDS, TH are expressed in $\mathrm{mg} / \mathrm{L}, \mathrm{EC}$ is in $\mu \mathrm{S} / \mathrm{cm}, \mathrm{pH}$ unites, $\mathrm{SW}$ Surface water and $\mathrm{BH}$ Bore hole water/groundwater
3). A major portion of the study area (95\%) contains $\mathrm{Mg}^{2+}$ within its maximum approved limit $150 \mathrm{mg} / \mathrm{L}$, and in about four (SW-1, SW-2, SW-3, SW-4) surface water samples and eight (BH-1, BH-14, BH-16, BH-18, BH-17, BH-21, $\mathrm{BH}-22, \mathrm{BH}-25)$ groundwater samples the concentration exceeds the maximum desirable limit $<30 \mathrm{mg} / \mathrm{L}$ (Table 2). The $\mathrm{HCO}_{3}{ }^{-}$is the dominant anion in the study area and surface water and groundwater samples concentration ranges from 360 to $470 \mathrm{mg} / \mathrm{L}$ and 299 to $628 \mathrm{mg} / \mathrm{L}$ with an average value of $422 \mathrm{mg} / \mathrm{L}$ and $408 \mathrm{mg} / \mathrm{L}$, respectively (Tables 2, 3). Deepali et al. (2012) have confirmed that the $\mathrm{SO}_{4}{ }^{2-}$ is one of the naturally occurring and recurrently present in surface and groundwater of leaching from gypsum and other common minerals and at ingestion of higher concentration of $\mathrm{SO}_{4}{ }^{2-}$ may lead to gastrointestinal irritation. So, the present analytical data show that $\mathrm{SO}_{4}{ }^{2-}$ concentration in surface water and groundwater samples varied from 27 to $140 \mathrm{mg} / \mathrm{L}$ and 18 to $240 \mathrm{mg} / \mathrm{L}$, with an average value of $89.6 \mathrm{mg} / \mathrm{L}$ and $70.3 \mathrm{mg} / \mathrm{L}$, respectively (Tables 2,3 ), of which only one sample (BH-16) exceeded the maximum desirable limit 200 mg/L (BIS 2003; WHO 1997; Table 3). $\mathrm{Cl}^{-}$majorly derives from the different sources such as domestic wastage, industrial wastes, municipal effluents and weathering of rocks, and it is considered as an index of pollution (Karanth 1987; Hem 1985; Loizidou and Kapetanios 1993). The $\mathrm{Cl}^{-}$content in the surface water and groundwater samples varied from 40 to $545 \mathrm{mg} / \mathrm{L}$ and 10 to $785 \mathrm{mg} / \mathrm{L}$, with an average $245 \mathrm{mg} / \mathrm{L}$ and $218 \mathrm{mg} / \mathrm{L}$, respectively; $20 \%$ of samples from surface water whereas $40 \%$ of groundwater samples exceeded the desirable limits (BIS 2003; WHO 1997; Tables 2, 3). However, in the remaining surface water and groundwater samples, the $\mathrm{Cl}^{-}$concentration is below the maximum permissible limits. Fluoride contamination in groundwater is one of the foremost issues in water quality

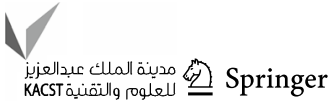


Table 3 Minimum, maximum and mean of groundwater and surface water samples from the study area and its analytical data and comparison with the WHO and BIS standards for drinking purposes

\begin{tabular}{|c|c|c|c|c|c|c|c|c|c|c|c|c|}
\hline & $\mathrm{pH}$ & $\mathrm{EC}$ & TDS & $\mathrm{TH}$ & $\mathrm{Ca}^{2+}$ & $\mathrm{Mg}^{2+}$ & $\mathrm{Na}^{+}$ & $\mathrm{K}^{+}$ & $\mathrm{HCO}_{3}^{-}$ & $\mathrm{SO}_{4}{ }^{2-}$ & $\mathrm{Cl}^{-}$ & $\mathrm{F}^{-}$ \\
\hline \multirow[t]{2}{*}{ Minimum } & $7^{\mathrm{a}}$ & 676 & 446 & 280 & 24 & 15 & 129 & 2 & 299 & 18 & 10 & 0.84 \\
\hline & $7.2^{\mathrm{b}}$ & 902 & 595 & 285 & 56 & 25 & 131 & 1.4 & 360 & 27 & 40 & 0.63 \\
\hline \multirow[t]{2}{*}{ Maximum } & $8.4^{\mathrm{a}}$ & 4016 & 2650 & 1185 & 242 & 176 & 545 & 6 & 628 & 240 & 785 & 1.85 \\
\hline & $7.8^{\mathrm{b}}$ & 2860 & 1887 & 870 & 92 & 56 & 400 & 4 & 470 & 140 & 545 & 0.81 \\
\hline \multirow[t]{2}{*}{ Mean } & $7.6^{\mathrm{a}}$ & 1489.7 & 985.6 & 470 & 77.2 & 42.6 & 214.8 & 2.6 & 408.5 & 70.3 & 245 & 1.22 \\
\hline & $7.5^{\mathrm{b}}$ & 1630.4 & 1075.8 & 421 & 71.6 & 38.8 & 193.6 & 2,3 & 422 & 89.6 & 245 & 0.69 \\
\hline WHO DL & 6.5 & - & 500 & 100 & 75 & 50 & - & - & - & 200 & 200 & 0.6 \\
\hline$\%$ of samples above DL & $100^{\mathrm{a}}$ & - & 96 & 100 & 48 & 24 & - & - & - & 4 & 40 & 100 \\
\hline WHO PL & 8.5 & - & 1500 & 500 & 200 & 150 & 200 & 12 & - & 400 & 600 & 1.5 \\
\hline$\%$ of samples above DL & $\mathrm{Nil}^{\mathrm{a}}$ & - & 20 & 28 & 4 & 4 & 48 & Nil & - & Nil & 4 & 32 \\
\hline BIS DL & 6.5 & - & 500 & 300 & 75 & 30 & - & - & - & 200 & 250 & 1 \\
\hline$\%$ of samples above DL & $100^{\mathrm{b}}$ & - & 100 & 100 & 40 & 100 & - & - & - & Nil & 20 & Nil \\
\hline BIS PL & 8.5 & - & 2000 & 600 & 200 & 100 & - & - & - & 400 & 1000 & 1.2 \\
\hline$\%$ of samples above DL & $\mathrm{Nil}^{\mathrm{b}}$ & - & Nil & 20 & Nil & Nil & - & - & - & Nil & Nil & Nil \\
\hline
\end{tabular}

$\mathrm{Ca}^{2+}, \mathrm{Mg}^{2+}, \mathrm{Na}^{+}, \mathrm{K}^{+}, \mathrm{HCO}_{3}{ }^{-}, \mathrm{SO}_{4}{ }^{2-}, \mathrm{Cl}^{-}, \mathrm{F}^{-}$, TDS, TH are expressed in $\mathrm{mg} / \mathrm{L}, \mathrm{EC}$ is in $\mu \mathrm{S} / \mathrm{cm}, \mathrm{pH}$ unites

$D L$ desirable limit, $P L$ permissible limit

${ }^{\mathrm{a}}$ Groundwater, ${ }^{\mathrm{b}}$ surface water

Table 4 Distribution of water samples based on the classification of TDS

\begin{tabular}{lllcc}
\hline Water type & $\begin{array}{l}\text { TDS concentration } \\
(\mathrm{mg} / \mathrm{L})\end{array}$ & Sample numbers below the limits & $\begin{array}{l}\% \text { of ground- } \\
\text { water }\end{array}$ & $\begin{array}{c}\% \text { of } \\
\text { surface } \\
\text { water }\end{array}$ \\
\hline Fresh & $<1000$ & $\begin{array}{l}\text { SW-1, SW-3 to 5, BH-3, BH- 5 to BH-13, BH-15, BH-19, BH-20 } \\
\text { BH-22 to BH-25 }\end{array}$ & 68 \\
Brackish & $>1000$ & SW-2, BH-1, BH-2, BH-4, BH-14, BH-16 to BH-18, BH-20 & 32 & - \\
Saline & $>10,000$ & - & - & - \\
Brine & 100,000 & - & - & - \\
\hline
\end{tabular}

Table 5 Distribution of water samples based on the classification of $\mathrm{TH}$

\begin{tabular}{lllll}
\hline Water type & $\begin{array}{l}\text { TH con- } \\
\text { centration } \\
(\mathrm{mg} / \mathrm{L})\end{array}$ & $\begin{array}{l}\text { Sample num- } \\
\text { bers below } \\
\text { the limits }\end{array}$ & $\begin{array}{l}\text { \% of } \\
\text { ground- } \\
\text { water }\end{array}$ & $\begin{array}{l}\text { \% of } \\
\text { surface } \\
\text { water }\end{array}$ \\
\hline Safe & $<75$ & - & - & - \\
Moderately hard & $75-150$ & - & - & - \\
Hard & $150-300$ & SW-1, BH-23 & 4 & 20 \\
Very hard & $>300$ & SW-2 to 5, \\
& BH-1 to \\
& 22, BH-24, \\
BH-25 & 80 \\
\end{tabular}

studies (Ayoob and Gupta 2006; Narsimha and Sudarshan 2017a, b; Narsimha 2012). Fluorite $\left(\mathrm{CaF}_{2}\right)$ is the only principal mineral of fluorine, mostly present as accessory minerals in granitic and occasionally in alkaline rocks (e.g. syenite and nepheline syenites). Apatite, amphiboles and micas, which are ubiquitous in igneous and metamorphic rocks, contain fair amounts of fluorine in their structure (Handa 1975; Adimalla and Venkatayogi 2017; Wenzel and Blum 1992; Narsimha and Sudarshan 2017a, b). Koritnig (1951) has obviously illustrated that fluoride is percolated in the initial stages of weathering of granite massifs. The maximum acceptance limit of fluoride in drinking water specified by the World Health Organization WHO (1997) is $1.5 \mathrm{mg} / \mathrm{L}$. Fluoride $\left(\mathrm{F}^{-}\right)$is an essential element for human body when consumed in low amount $(<1.5 \mathrm{mg} / \mathrm{L})$ and excess intake of $\mathrm{F}^{-}(>1.5 \mathrm{mg} / \mathrm{L})$ will have adverse effects on human health (Adimalla and Venkatayogi 2017; Adimalla et al. 2018b, c; Narsimha and Sudarshan 2017a, b). Furthermore, continually consumption of water with fluoride concentrations above $1.5 \mathrm{mg} / \mathrm{L}$ results in dental fluorosis characterized initially by opaque white patches, staining, mottling and pitting of teeth (Adimalla et al. 2018c; Narsimha and Rajitha 2018; Narsimha 2018; Narsimha et al. 2018; Kundu et al. 2001). 
Moreover, $\mathrm{F}^{-}$concentration in surface water and groundwater of the study area varied from 0.63 to $0.81 \mathrm{mg} / \mathrm{L}$ and 0.84 to $1.85 \mathrm{mg} / \mathrm{L}$, with mean value of 0.69 and $1.22 \mathrm{mg} / \mathrm{L}$, respectively (Tables 2,3 ). Surface water is within the maximum permissible limits, besides $32 \%$ of groundwater samples having higher concentrations above the maximum permissible limits (Table 3 ). Low content ( $<1 \mathrm{mg} / \mathrm{L}$ ) of fluoride implies near absence of fluoride-bearing minerals, and higher concentrations $(>1.5 \mathrm{mg} / \mathrm{L})$ of fluoride are prominent in the southern part of the study area.

\section{Spatial distribution of physico-chemical parameters}

The hydrogeochemical study with geographical information system (GIS) divulges the zones where the quality of water is suitable for drinking and agricultural purposes. In any area around the world, groundwater quality and spatial distribution maps are significant as protective indicators of potential risk environmental health problems. GIS has been widely used to create spatial distribution maps, which are indicators of suitable and unsuitable zones (Sheikh et al. 2017; Sudhakar and Narsimha 2013; Narsimha et al. 2013a, b; Panaskar et al. 2016; Sudarshan et al. 2014; Amiri et al. 2015; Sappa et al. 2015). In this study, spatial distribution maps are prepared for $\mathrm{pH}$, electrical conductivity (EC), total dissolved solids (TDS), total hardness (TH), bicarbonate $\left(\mathrm{HCO}_{3}{ }^{-}\right)$, chloride $\left(\mathrm{Cl}^{-}\right)$, sulphate $\left(\mathrm{SO}_{4}{ }^{2-}\right)$, fluoride $\left(\mathrm{F}^{-}\right)$, calcium $\left(\mathrm{Ca}^{2+}\right)$, magnesium $\left(\mathrm{Mg}^{2+}\right)$, sodium $\left(\mathrm{Na}^{+}\right)$ and potassium $\left(\mathrm{K}^{+}\right)$of the groundwater to delineate the safe and unsafe zones. $\mathrm{pH}$ spatial distribution map of the study area is depicted in Fig. 2, and it demonstrates that more than half the area is under alkaline nature. The spatial distribution map of the electrical conductivity in the study area is shown in Fig. 3. Distribution map of TDS is shown in Fig. 4, in which southern part of the study region is having high concentrations up to $2650 \mathrm{mg} / \mathrm{L}$. Figure 5 shows the spatial distribution map of TH. Spatial distribution map indicates that in majority of the locations the $\mathrm{TH}$ is above the desirable limit of $100 \mathrm{mg} / \mathrm{L}$ and southern part of the study region having higher concentration, which is above the maximum permissible limit of $500 \mathrm{mg} / \mathrm{L}$. Higher concentration of $\mathrm{Na}^{+}$was in patches of eastern, western and southern part of the study area, which is clearly illustrated in Fig. 6. Spatial distribution map of $\mathrm{Ca}^{2+}$ (Fig. 7) shows that central part of the region is very low in concentration comparing to eastern, western and southern parts. Additionally, the spatial distribution of $\mathrm{K}^{+}, \mathrm{Mg}^{2+}$ and $\mathrm{HCO}_{3}{ }^{-}$concentration is shown in Figs. 8, 9 and 10 respectively. Spatial distribution of $\mathrm{SO}_{4}^{2-}$ is shown in Fig. 11, and it clearly indicates that the high concentration is in southern and small patches from western part and low concentration is in northern part, and eventually it shows dissimilar concentrations throughout the study region, due to changes in infiltration of rainfall. The concentration of $\mathrm{Cl}^{-}$was relatively high in eastern and western parts of the study area (Fig. 12). Figure 13 shows the spatial distribution map of fluoride which shows that maximum area is under the permissible limits and southern and eastern parts of the study area is having higher concentration $(>1.5 \mathrm{mg} / \mathrm{L})$ in the study area. Moreover, it is observed that fluoride, bicarbonate, chloride, sulphate, calcium, magnesium, sodium and potassium concentrations are less in surface water when compared to groundwater (Fig. 14).
Fig. 2 Spatial Distribution map of $\mathrm{pH}$ in Mothkur region, Telangana State, South India

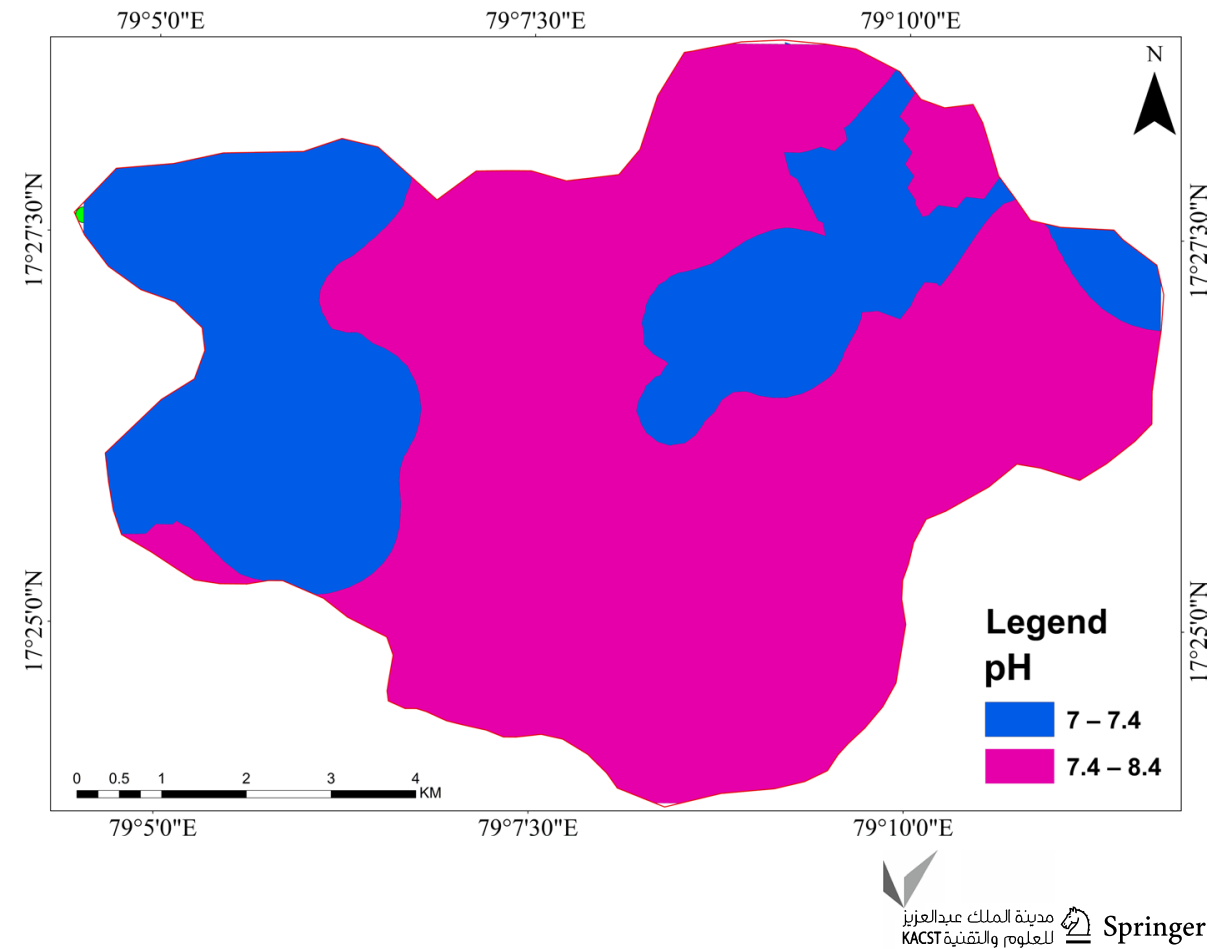


Fig. 3 Spatial distribution map of EC $(\mu \mathrm{S} / \mathrm{cm})$ in Mothkur region, Telangana State, South India

Fig. 4 Spatial distribution map of TDS in Mothkur region, Telangana State, South India
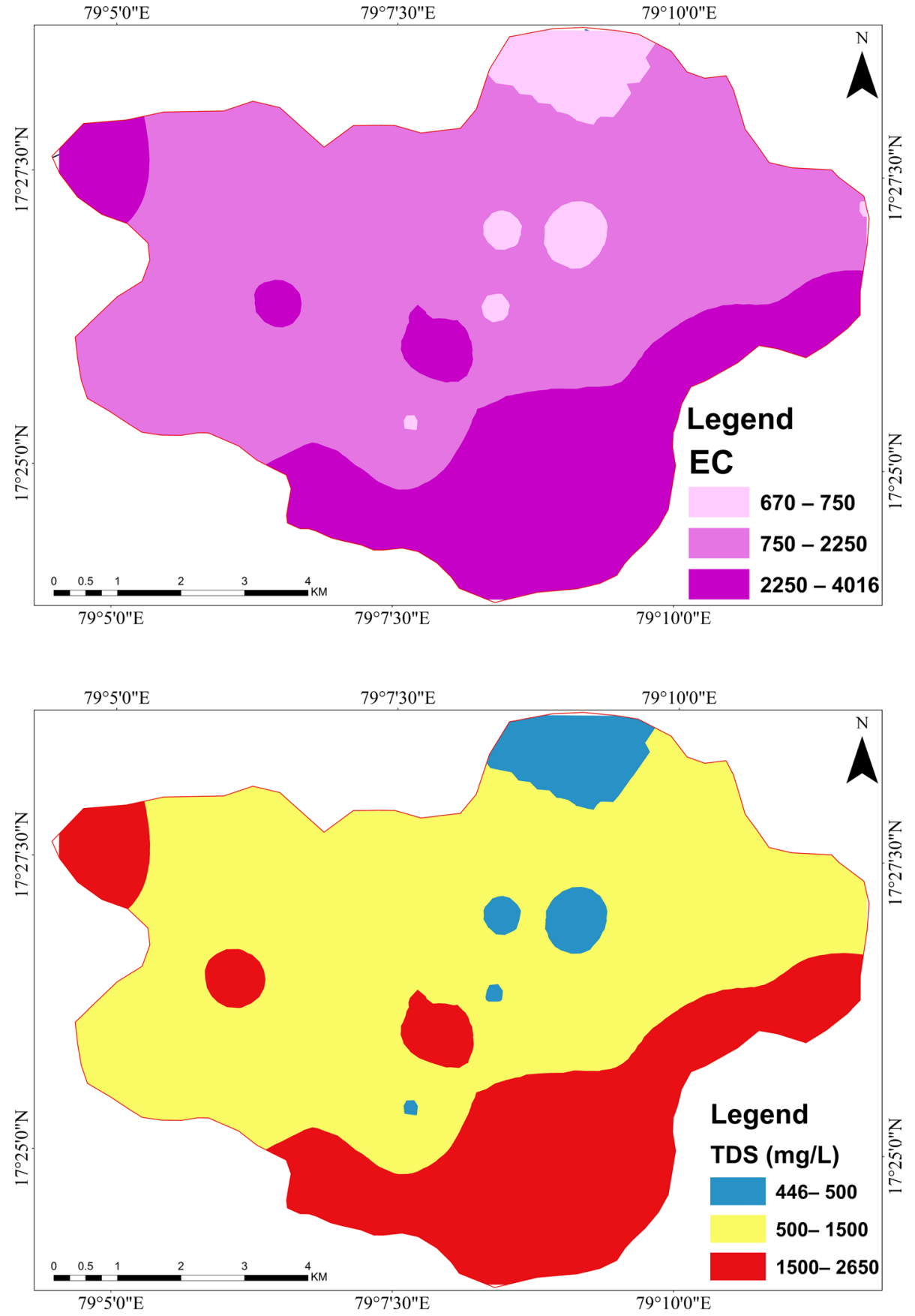

\section{Hydrogeochemical evaluation}

The analyses data reveals that the $\mathrm{Na}^{+}$concentration is high in the study region. There are two reasons for higher $\mathrm{Na}^{+}$ concentration, i.e. halite dissolution and silicate weathering. For this, $\mathrm{Na}^{+} / \mathrm{Cl}^{-}$ratio plays vital and if $\mathrm{Na}^{+} / \mathrm{Cl}^{-}<1$ the halite dissolution is responsible for high sodium, whereas if $\mathrm{Na}^{+} / \mathrm{Cl}^{-}>1, \mathrm{Na}^{+}$is released from silicate weathering (Meybeck 1987). In the present study, the molar ratio $\mathrm{Na}^{+} / \mathrm{Cl}^{-}$of water samples ranges from 0.63 to $19.89 \mathrm{meq} / \mathrm{L}$, and for $80 \%$ of the samples $\mathrm{Na}^{+} / \mathrm{Cl}^{-}$ratio is more than 1 , which indicates that the $\mathrm{Na}^{+}$derives from silicate weathering (Stallard and Edmond 1983; Narsimha and Sudarshan 2017a; Fig. 15a; Supplementary material Table 1 ). Moreover, $\mathrm{Na}^{+}$versus TDS scatter plot shown in Fig. $15 \mathrm{~b}$ reveals that $\mathrm{Na}^{+}$concentration shows an increasing trend with increasing TDS and in addition to the weathering of silicate minerals it might be related to the anthropogenic sources such as sewage, domestic waste (Williams et al. 1999; Choi et al. 2005). In addition, $\mathrm{Na}^{+} /\left(\mathrm{Na}^{+}+\mathrm{Cl}^{-}\right)$molar ratio was calculated, and $93 \%$ of water locations have above $0.5 \mathrm{meq} / \mathrm{L}$ (Supplementary 
Fig. 5 Spatial distribution map of TH in Mothkur region, Telangana State, South India
Fig. 6 Spatial distribution map of $\mathrm{Na}^{+}$in Mothkur region, Telangana State, South India
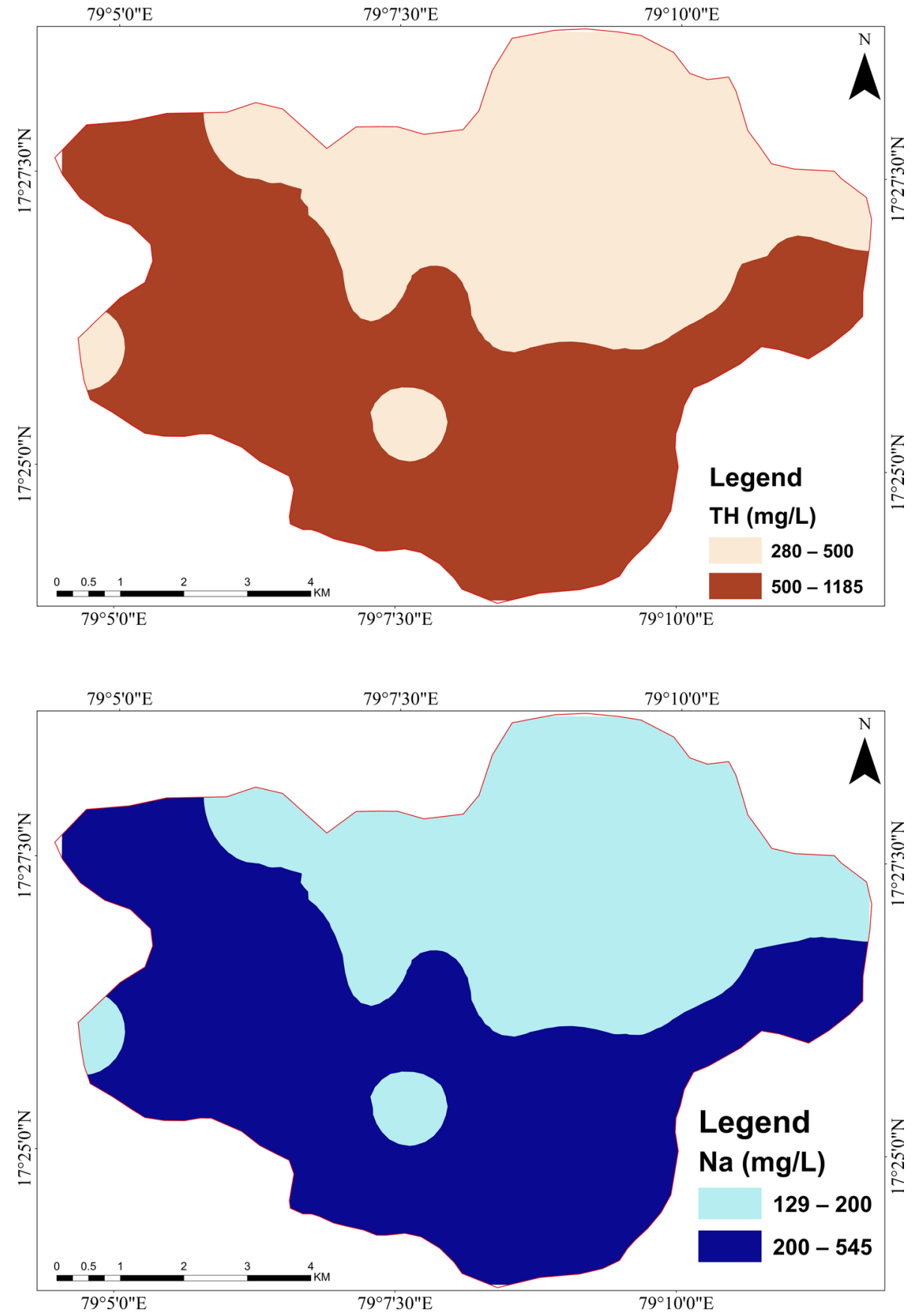

material Table 1), which indicates that $\mathrm{Na}^{+}$derives not from the halite and other source like silicate weathering (Fig. 15d) and ion exchange process (Hounslow 1995). Furthermore, Jankowski and Acworth (1997) have used $\mathrm{Na}^{+} / \mathrm{Cl}^{-}$ratio vs EC, which would be an effective indicator to estimate the evaporation dominant process. Hence, Fig. 15c clearly reveals that the trend line is inclined, and $\mathrm{Na}^{+} / \mathrm{Cl}^{-}$ratio decreases with increasing $\mathrm{EC}$ which indicates that evaporation is not the major controlling process in groundwater chemistry in this terrain.

\section{Classification of water samples}

IIED (2002) and Soltan (1998) have proposed classification of water based on the milliequivalent per litre (meq/L) content of chloride, sulphate and bicarbonates. The water is normal $\mathrm{Cl}^{-}$type if $\mathrm{Cl}^{-}$is $<15 \mathrm{meq} / \mathrm{L}$, normal $\mathrm{SO}_{4}{ }^{2-}$ type if $\mathrm{SO}_{4}{ }^{2-}$ is $<6 \mathrm{meq} / \mathrm{L}$ and normal $\mathrm{HCO}_{3}{ }^{-}$type if $\mathrm{HCO}_{3}{ }^{-}$varies between 2 and $7 \mathrm{meq} / \mathrm{L}$. Detailed distribution of water samples based on the (APHA 1992; IIED 2002; Soltan 1998) classification has showed that the majority of the samples 
Fig. 7 Spatial distribution map of $\mathrm{Ca}^{2+}$ in Mothkur region, Telangana State, South India
Fig. 8 Spatial distribution map of $\mathrm{K}^{+}$in Mothkur region, Telangana State, South India
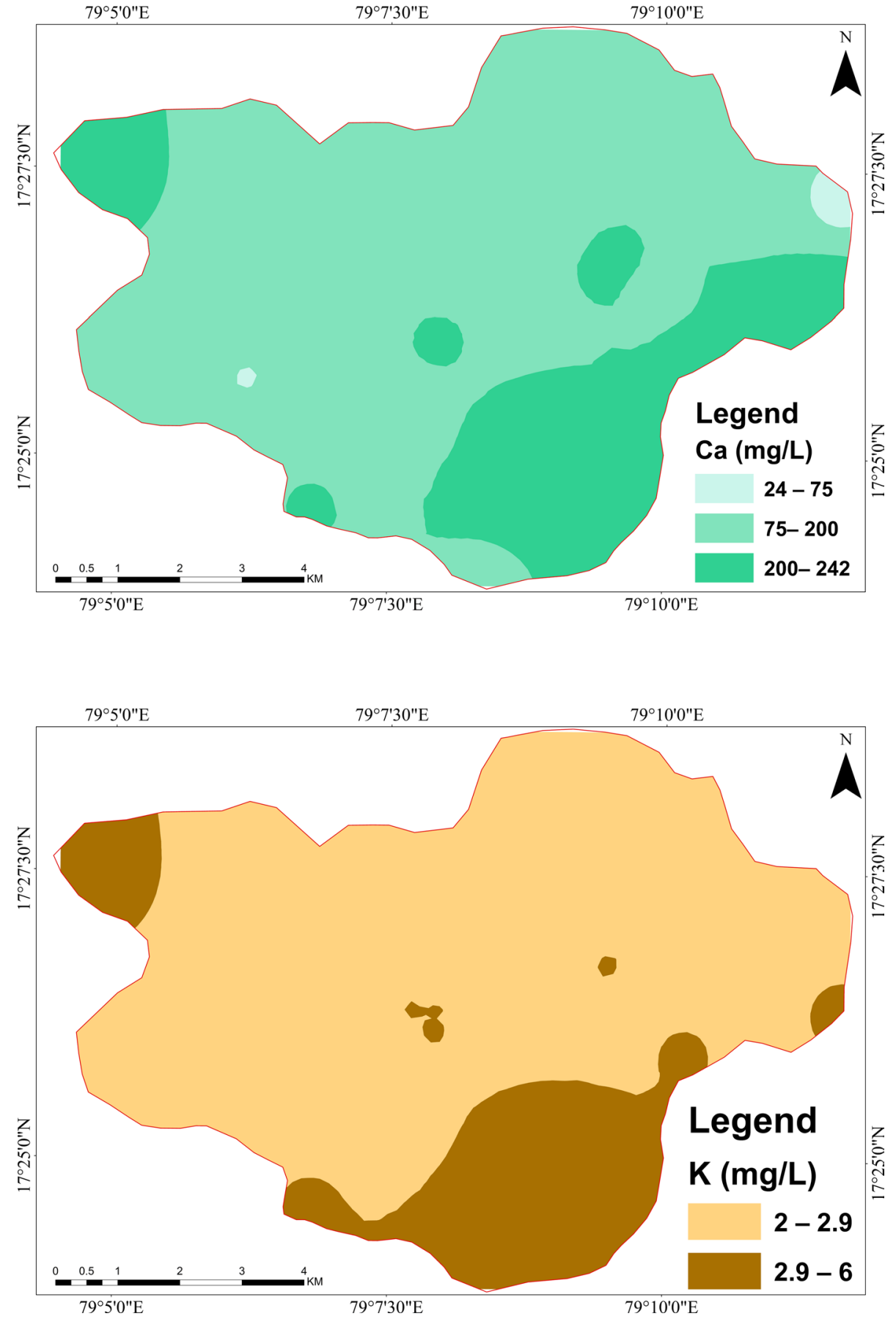

belongs to normal sulphate, normal chloride and finally normal bicarbonate (Table 6).

\section{Base-exchange indices (BEI) and meteoric genesis indices (MGI)}

The base-exchange indices (BEI) and meteoric genesis indices (MGI) (Matthess 1982; Soltan 1998, 1999) were determined by using Eqs. 1 and 2, respectively. These are very worthwhile for the further classification of groundwater.

$$
\begin{aligned}
& \mathrm{BEI}=\left[\mathrm{Na}^{+}-\mathrm{Cl}^{-}\right] / \mathrm{SO}_{4}^{2-} \\
& \mathrm{MGI}=\left[\left(\mathrm{Na}^{+}+\mathrm{K}^{+}\right)-\mathrm{Cl}^{-}\right] / \mathrm{SO}_{4}^{2-}
\end{aligned}
$$


Fig. 9 Spatial distribution map of $\mathrm{Mg}^{2+}$ in Mothkur region, Telangana State, South India
Fig. 10 Spatial distribution map of $\mathrm{HCO}_{3}{ }^{-}$in Mothkur region, Telangana State, South India
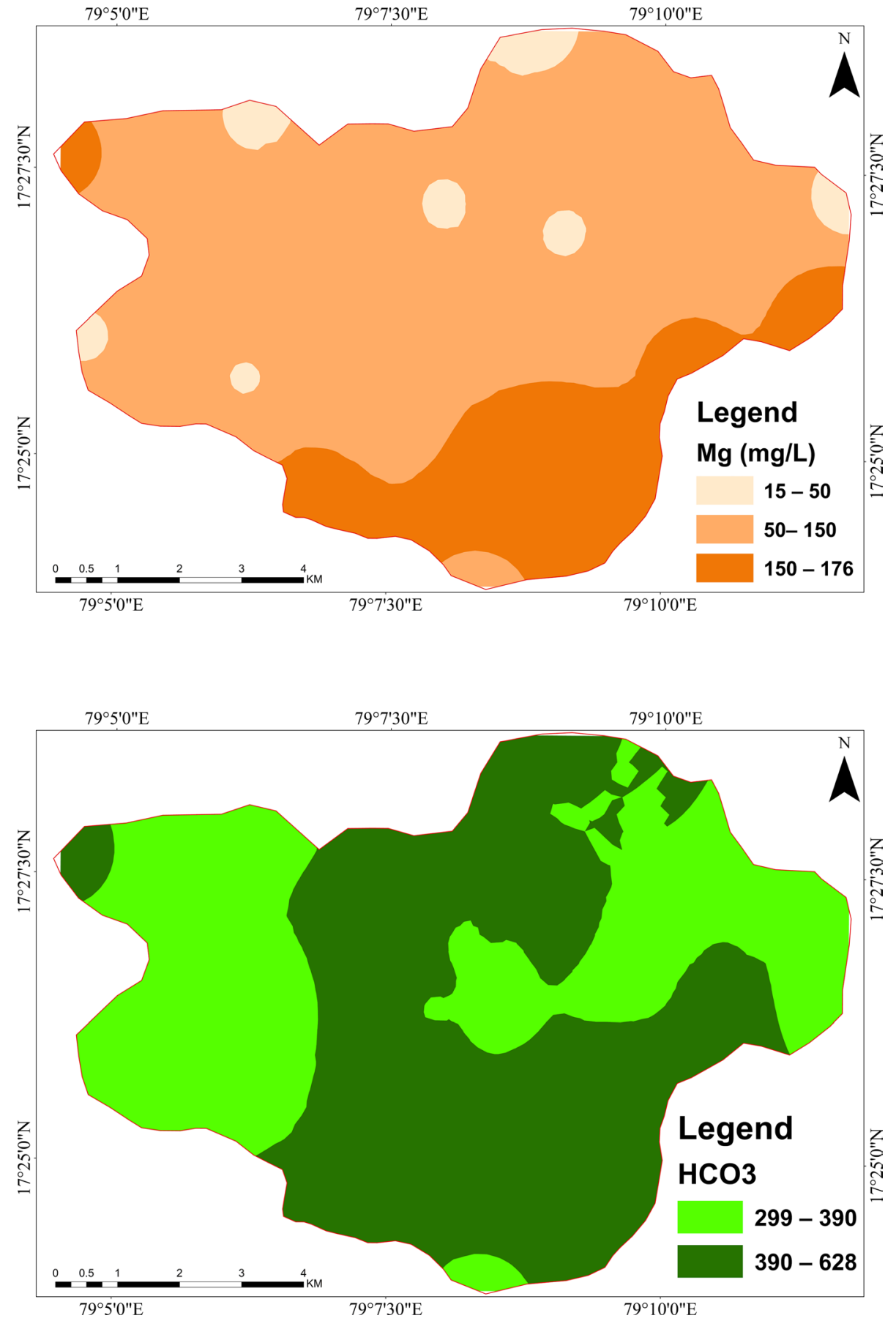

where all ionic $\left(\mathrm{Na}^{+}, \mathrm{K}^{+}, \mathrm{Cl}^{-}, \mathrm{SO}_{4}{ }^{2-}\right)$ concentrations are expressed in $\mathrm{meq} / \mathrm{L}$. The water can be arranged in different groups as $\mathrm{Na}^{+}-\mathrm{HCO}_{3}{ }^{-}$type if $\mathrm{BEI}>1$ and $\mathrm{Na}^{+}-\mathrm{SO}_{4}{ }^{2-}$ type with $\mathrm{BEI}<1$, whereas the water source is of deep meteoric water percolation type if $\mathrm{MGI}<1$ and MGI $>1$ indicates that the water is of shallow meteoric percolation type and also its detailed illustration has been presented in Table 7 .

\section{Hydrogeochemical facies and water types}

The Piper (1944) trilinear diagram is very useful to reveal the water types based on the ionic composition of surface water and groundwater from the different aquifers (Narsimha and Sudarshan 2017a, b; Adimalla and Venkatayogi 2017; Subba Rao et al. 2012; Li et al. 2012), and it is a very effective tool to identify the chemical relationship in water samples. This diagram contains two triangular charts 
Fig. 11 Spatial distribution map of $\mathrm{SO}_{4}{ }^{2-}$ in Mothkur region, Telangana State, South India
Fig. 12 Spatial distribution map of $\mathrm{Cl}^{-}$in Mothkur region, Telangana State, South India
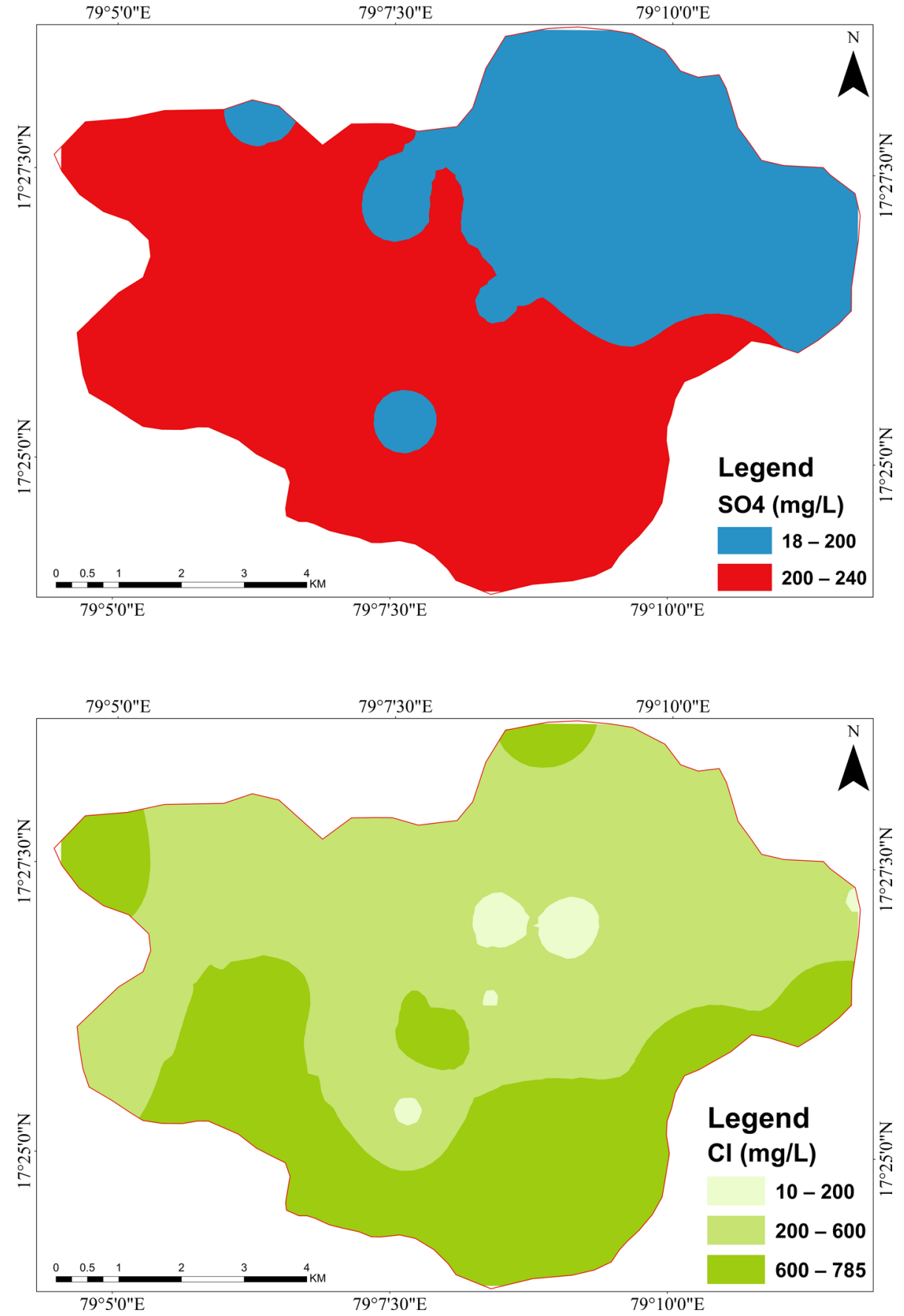

for depicting the proportions of cations $\left(\mathrm{Na}^{+}, \mathrm{Ca}^{2+}, \mathrm{K}^{+}\right.$, $\left.\mathrm{Mg}^{2+}\right)$ and anions $\left(\mathrm{CO}_{3}{ }^{2-}, \mathrm{HCO}_{3}{ }^{-}, \mathrm{SO}_{4}{ }^{2-}, \mathrm{Cl}^{-}\right)$, expressed in meq/L. The triangle for cations has $100 \% \mathrm{Ca}^{2+}$ in the left corner, $100 \% \mathrm{Na}^{+}+\mathrm{K}^{+}$towards the right and $100 \%$ $\mathrm{Mg}^{2+}$ upwards and for anions it has $100 \%$ carbonates and bicarbonates to the left, $100 \% \mathrm{Cl}^{-}$to the right and $100 \% \mathrm{SO}_{4}{ }^{2-}$ on top. The obtained chemical data values from the different water samples collected from the study region are plotted on the Piper (1944) diagram Fig. 16. On the basis of Piper diagram, collected water of the study area are divided into six types, that are $\mathrm{Ca}^{2+}-\mathrm{HCO}_{3}{ }^{-}$, $\mathrm{Na}^{+}-\mathrm{Cl}^{-}$, mixed $\mathrm{Ca}^{2+}-\mathrm{Na}^{+}-\mathrm{HCO}_{3}{ }^{-}$, mixed $\mathrm{Ca}^{2+}-\mathrm{Mg}^{2+}-\mathrm{Cl}^{-}$, $\mathrm{Na}^{+}-\mathrm{Cl}^{-}$and $\mathrm{Na}^{+}-\mathrm{HCO}_{3}{ }^{-}$. The prevalent water types are mixed $\mathrm{Ca}^{2+}-\mathrm{Na}^{+}-\mathrm{HCO}_{3}^{-}>\mathrm{Na}^{+}-\mathrm{Cl}^{-}>\mathrm{Na}^{+}-\mathrm{HCO}_{3}{ }^{-}$identified in the Mothkur region. About $44 \%$ and $60 \%$ collected groundwater and surface water samples are significantly dominated by mixed $\mathrm{Ca}^{2+}-\mathrm{Na}^{+}-\mathrm{HCO}_{3}{ }^{-}, 30 \%$ is from $\mathrm{Na}^{+}-\mathrm{Cl}^{-}$and eventually, $29 \%$ of water samples was from $\mathrm{Na}^{+}-\mathrm{HCO}_{3}{ }^{-}$(Fig. 16). In the study area, chemical analysis reveals that the $\mathrm{HCO}_{3}{ }^{-}$and $\mathrm{Na}^{+}$concentrations are high with 
Fig. 13 Spatial distribution map of $\mathrm{F}^{-}$in Mothkur region, Telangana State, South India

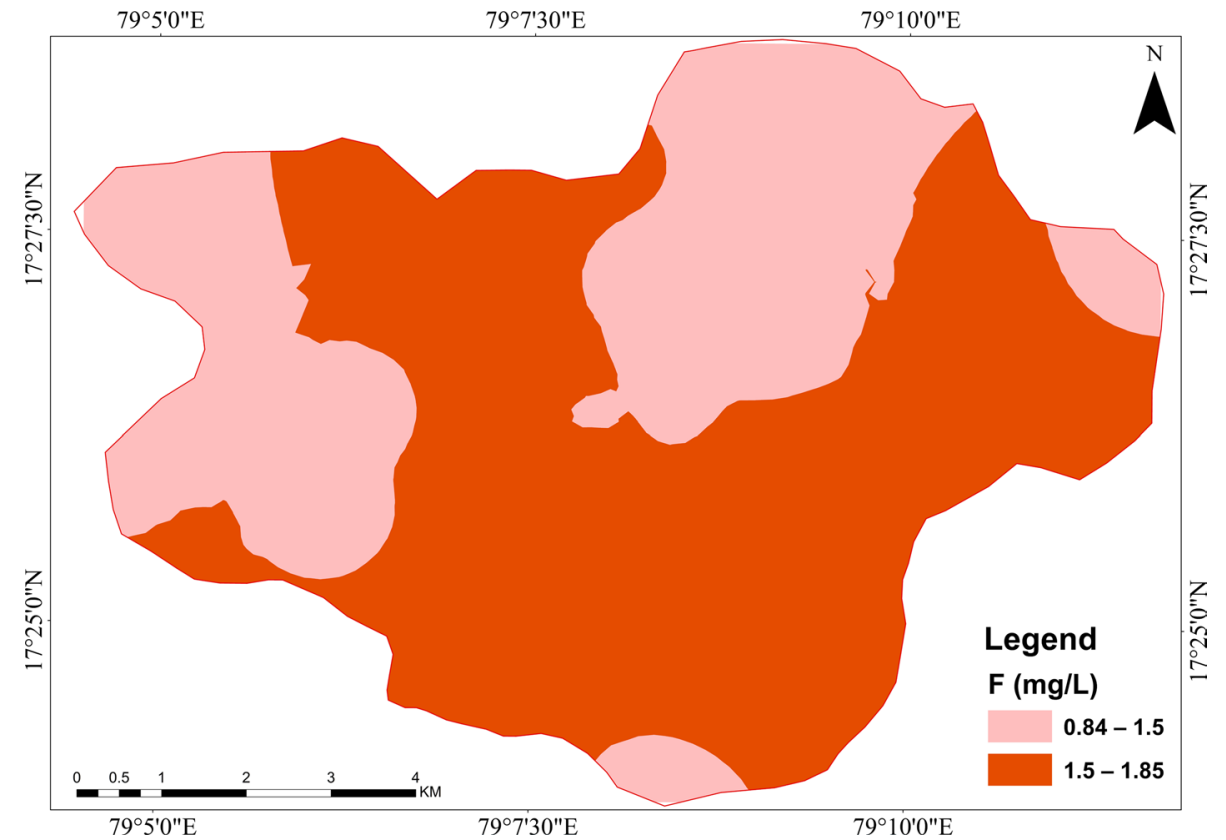

other ions, and it is because of the entire study area occupied by crystalline hard rocks, where silicate minerals are generally present. Therefore, high $\mathrm{HCO}_{3}{ }^{-}$and $\mathrm{Na}^{+}$concentration and high $\mathrm{pH}$ values are controlled by the rock-water interaction (Adimalla and Venkatayogi 2017; Narsimha and Sudarshan 2017a, b).

\section{Multivariate graphical methods for irrigation utility}

It is necessary to know the suitability of surface water and groundwater for irrigation/agricultural purposes depending on the effect of mineral constituents of the water on both plants and soils (Wilcox 1955; Richards 1954). For this, the effective multivariate graphical methods are used to determine its suitability for agricultural needs, that are EC, sodium adsorption ratio (SAR), per cent of sodium $(\% \mathrm{Na})$, residual sodium carbonate (RSC) and permeability index (PI) playing a vital role in suitability of water for irrigation, and these graphical methods are extensively used all over the world (Li et al. 2014a, 2017b; Sappa et al. 2015; Ghazaryan and Chen 2016; Panaskar et al. 2016; Amiri et al. 2015; Li et al. 2012). The classifications of irrigation water, based on SAR, \% Na, RSC and EC are reviewed in Tables 8 and 9. It is well known that EC and SAR are good measures for salinity hazard and sodium hazard to crops, respectively (Tables 9, 10). The US Salinity Laboratory's diagram (1954) is used broadly to assess the irrigation waters, where SAR is plotted against EC (Fig. 17) and shows that $44 \%$ and $60 \%$ of the groundwater and surface water samples fall in the category of $\mathrm{C} 3 \mathrm{~S} 1$, indicating water of high salinity and low sodium type, which is very useful for irrigation in almost all types of soils (US Salinity Laboratory Staff 1954; Table 10). However, $32 \%$ of the groundwater samples fall in the field of $\mathrm{C} 3 \mathrm{~S} 2$, indicating high salinity and medium sodium type, which can be used to irrigate salt-tolerant and semi-tolerant crops under favourable drainage conditions (US Salinity Laboratory Staff 1954; Table 10). About 24\% of the groundwater and surface water samples fall in the field of C4S2, indicating very high salinity and medium sodium type, and this type of water is not useful for irrigation. Eventually, $40 \%$ of the water samples fall in $\mathrm{C} 2 \mathrm{~S} 1$, indicating medium salinity and low sodium type which can be used for irrigation on all types of soil without danger of exchangeable sodium (Table 10). Moreover, sodium adsorption ratio (SAR) is widely used for determining the suitability of surface water and groundwater for irrigation (Todd 1980; Karanth 1987) and is expressed as below:

$\mathrm{SAR}=\frac{\mathrm{Na}^{+}}{\sqrt{\left(\mathrm{Ca}^{2+}+\mathrm{Mg}^{2+}\right) / 2}}$

where $\mathrm{Na}^{+}, \mathrm{Ca}^{2+}$ and $\mathrm{Mg}^{2+}$ are expressed in meq/L and Richards (1954) classified SAR values into four groups (Table 9). In the present study, the SAR values varied from 3.38 to 8.19 and 3.36 to 4.83 for groundwater and surface water, respectively, indicating that the water of the study area has excellent quality for irrigation (Table 9). In addition, sodium concentration is another significant factor in classifying irrigation water, because sodium reacts with soil to affect the soil permeability and texture. Furthermore, sodium content is usually expressed in terms of per cent 

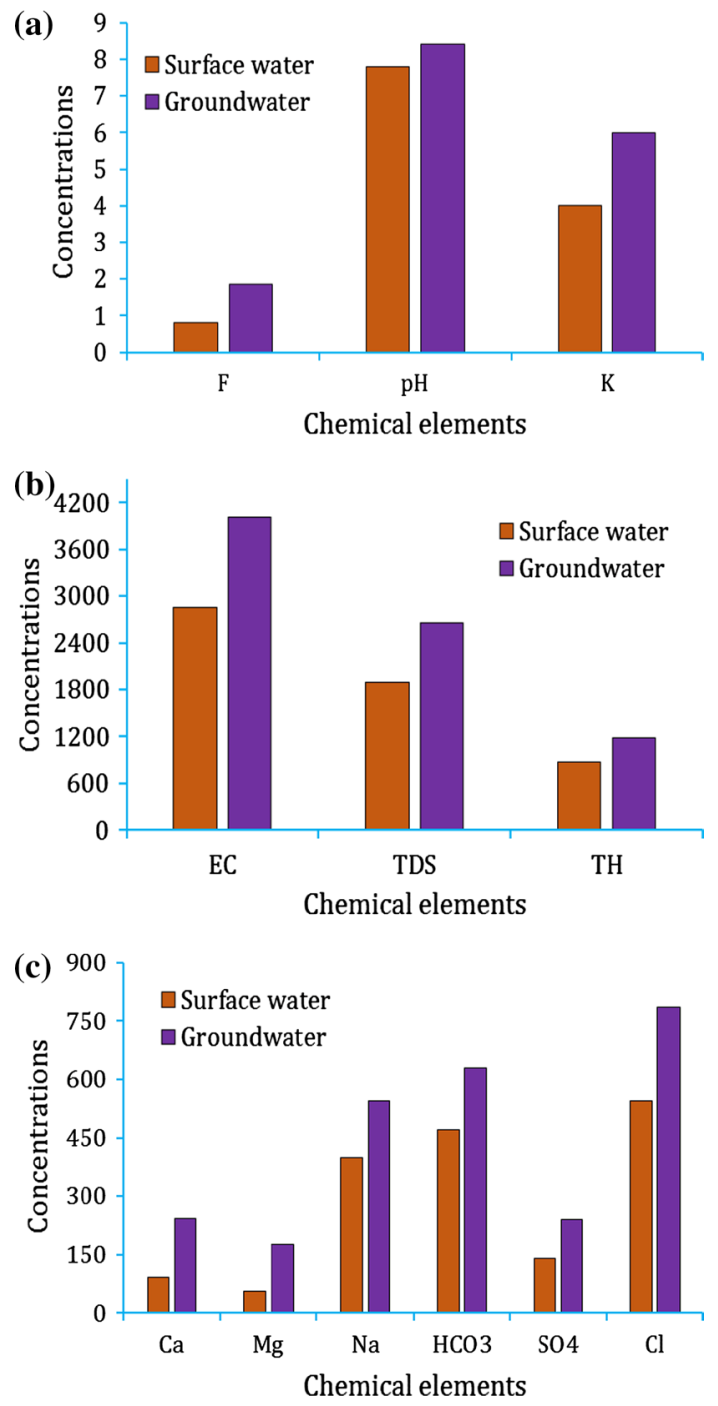

Fig. 14 Physico-chemical parameters concentrations and variation between groundwater and surface water samples in Mothkur region, Telangana State, South India

sodium (\%Na), which is calculated using the below formula given by Wilcox (1955):

$\% \mathrm{Na}=\frac{\mathrm{Na}^{+}+\mathrm{K}^{+}}{\left(\mathrm{Ca}^{2+}+\mathrm{Mg}^{2+}+\mathrm{Na}^{+}+\mathrm{K}^{+}\right)} \times 100$

where $\mathrm{Na}^{+}, \mathrm{K}^{+}, \mathrm{Ca}^{2+}$ and $\mathrm{Mg}^{2+}$ are expressed in meq/L. The $\% \mathrm{Na}$ in the study region ranges from $43.87 \%$ to $74.41 \%$ and $50.01 \%$ to $65.55 \%$ in the groundwater and surface water, respectively. About $56 \%$ of collected groundwater and $100 \%$ surface water are under permissible limits for irrigation, and remaining groundwater samples fall under doubtful category for irrigation (Wilcox 1955; Table 8), since they cause deflocculation and impairment of the tilth and the permeability of soil (Karanth 1989). However, Wilcox
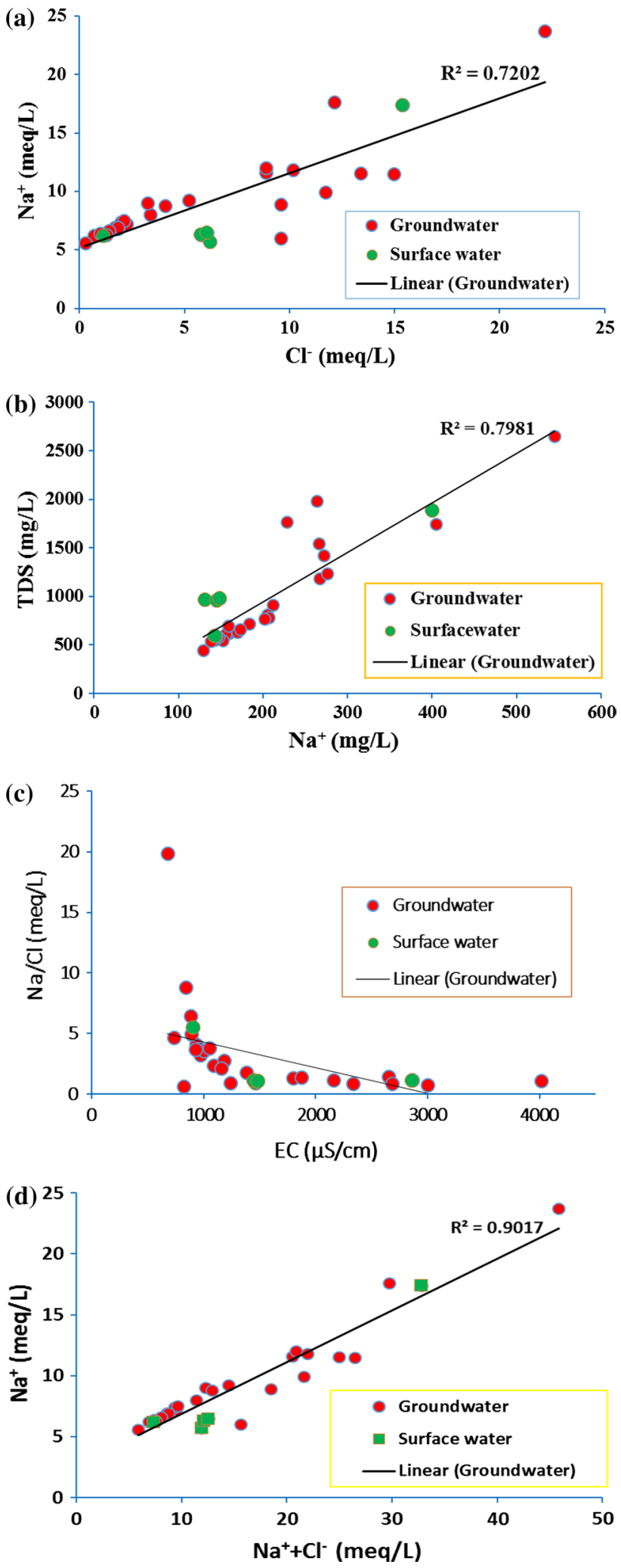

Fig. 15 Relation between $\mathbf{a ~ N a}{ }^{+}$and $\mathrm{Cl}^{-}, \mathbf{b ~ N a}{ }^{+}$and TDS, $\mathbf{c ~ N a}{ }^{+} / \mathrm{Cl}^{-}$ and $\mathrm{EC}, \mathbf{d ~ N a}{ }^{+}$and $\left(\mathrm{Na}^{+}+\mathrm{Cl}^{-}\right)$ 
Table 6 Groundwater and surface water classification according to $\mathrm{Cl}^{-}, \mathrm{SO}_{4}{ }^{2-}$ and $\mathrm{HCO}_{3}{ }^{-}$

\begin{tabular}{|c|c|c|c|c|}
\hline Concentrations (meq/L) & Sample numbers & $\begin{array}{l}\% \text { of ground- } \\
\text { water }\end{array}$ & $\begin{array}{l}\% \text { of surface } \\
\text { water }\end{array}$ & Water type \\
\hline $\mathrm{Cl}^{-}(<15)$ & SW-1, SW-3 to SW-5, BH-1 to BH-15, BH-17 to BH-25 & 96 & 80 & Normal \\
\hline $\mathrm{SO}_{4}{ }^{2-}(<6)$ & BH-1 to BH-25, SW-1 to SW-5 & 100 & 100 & Normal \\
\hline $\mathrm{HCO}_{3}^{-}(2-7)$ & 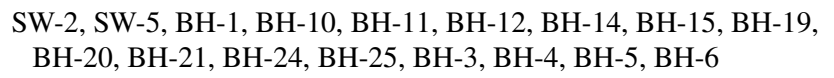 & 60 & 20 & Normal \\
\hline
\end{tabular}

Table 7 Groundwater and surface water classification according to base-exchange index (BGI) and meteoric genesis index (MGI) criteria

\begin{tabular}{|c|c|c|c|c|}
\hline Field label & BEI & Water type & MGI & Water type \\
\hline SW-1 & -0.30 & $\mathrm{Na}+\mathrm{SO}_{4}$ & -0.28 & Deep meteoric \\
\hline SW-2 & 0.69 & $\mathrm{Na}+\mathrm{SO}_{4}$ & 0.73 & Deep meteoric \\
\hline SW-3 & 0.33 & $\mathrm{Na}+\mathrm{SO}_{4}$ & 0.36 & Deep meteoric \\
\hline SW-4 & 0.16 & $\mathrm{Na}+\mathrm{SO}_{4}$ & 0.18 & Deep meteoric \\
\hline SW-5 & 9.06 & $\mathrm{Na}+\mathrm{HCO}_{3}$ & 9.15 & Shallow meteoric \\
\hline BH-1 & -0.88 & $\mathrm{Na}+\mathrm{SO}_{4}$ & -0.86 & Deep meteoric \\
\hline BH-2 & 1.64 & $\mathrm{Na}+\mathrm{HCO}_{3}$ & 1.68 & Shallow meteoric \\
\hline BH-3 & 1.63 & $\mathrm{Na}+\mathrm{HCO}_{3}$ & 1.66 & Shallow meteoric \\
\hline BH-4 & 1.87 & $\mathrm{Na}+\mathrm{HCO}_{3}$ & 1.90 & Shallow meteoric \\
\hline BH-5 & -0.28 & $\mathrm{Na}+\mathrm{SO}_{4}$ & -0.26 & Deep meteoric \\
\hline ВH-6 & 1.58 & $\mathrm{Na}+\mathrm{HCO}_{3}$ & 1.60 & Shallow meteoric \\
\hline BH-7 & 4.68 & $\mathrm{Na}+\mathrm{HCO}_{3}$ & 4.72 & Shallow meteoric \\
\hline BH-8 & 3.46 & $\mathrm{Na}+\mathrm{HCO}_{3}$ & 3.49 & Shallow meteoric \\
\hline ВН-9 & 7.17 & $\mathrm{Na}+\mathrm{HCO}_{3}$ & 7.24 & Shallow meteoric \\
\hline BH-10 & 4.73 & $\mathrm{Na}+\mathrm{HCO}_{3}$ & 4.78 & Shallow meteoric \\
\hline BH-11 & 4.48 & $\mathrm{Na}+\mathrm{HCO}_{3}$ & 4.52 & Shallow meteoric \\
\hline BH-12 & 5.17 & $\mathrm{Na}+\mathrm{HCO}_{3}$ & 5.22 & Shallow meteoric \\
\hline BH-13 & 5.43 & $\mathrm{Na}+\mathrm{HCO}_{3}$ & 5.48 & Shallow meteoric \\
\hline BH-14 & 3.51 & $\mathrm{Na}+\mathrm{HCO}_{3}$ & 3.60 & Shallow meteoric \\
\hline BH-15 & 7.81 & $\mathrm{Na}+\mathrm{HCO}_{3}$ & 7.88 & Shallow meteoric \\
\hline BH-16 & 0.31 & $\mathrm{Na}+\mathrm{SO}_{4}$ & 0.34 & Deep meteoric \\
\hline BH-17 & -1.60 & $\mathrm{Na}+\mathrm{SO}_{4}$ & -1.53 & Deep meteoric \\
\hline BH-18 & -1.15 & $\mathrm{Na}+\mathrm{SO}_{4}$ & -1.10 & Deep meteoric \\
\hline BH-19 & 10.60 & $\mathrm{Na}+\mathrm{HCO}_{3}$ & 10.69 & Shallow meteoric \\
\hline BH-20 & -9.58 & $\mathrm{Na}+\mathrm{SO}_{4}$ & -9.44 & Deep meteoric \\
\hline BH-21 & 1.55 & $\mathrm{Na}+\mathrm{HCO}_{3}$ & 1.62 & Shallow meteoric \\
\hline BH-22 & 13.67 & $\mathrm{Na}+\mathrm{HCO}_{3}$ & 13.80 & Shallow meteoric \\
\hline BH-23 & 10.67 & $\mathrm{Na}+\mathrm{HCO}_{3}$ & 10.77 & Shallow meteoric \\
\hline BH-24 & 12.10 & $\mathrm{Na}+\mathrm{HCO}_{3}$ & 12.22 & Shallow meteoric \\
\hline BH-25 & 8.35 & $\mathrm{Na}+\mathrm{HCO}_{3}$ & 8.49 & Shallow meteoric \\
\hline
\end{tabular}

$S W$ surface water, $B H$ bore hole water/groundwater

(1955) designed a graphical model for irrigation utility, where water has been classified into five classes which are excellent to good (EG), good to permissible (GP), permissible to doubtful (PD), doubtful to unsuitable (DUS) and unsuitable (Fig. 18). Wilcox diagram (Fig. 18) shows that out of twenty-five groundwater samples, $16 \%$ and $20 \%$ of the samples belong to excellent to good and good to permissible category, followed by $40 \%$ and $20 \%$ of the samples belonging to permissible to doubtful and doubtful to unsuitable, and all surface water samples belong to good to permissible category, which are suitable for irrigation (Fig. 18).

Residual sodium carbonate (RSC) of the water reveals that the bicarbonate value is very high compared to other anions (Tables 1, 2). Hence, carbonate ions $\left(\mathrm{HCO}_{3}^{-}+\mathrm{CO}_{3}{ }^{2-}\right)$ influence the water quality through the precipitation of alkaline earths $\left(\mathrm{Ca}^{2+}+\mathrm{Mg}^{2+}\right)$, where the water in the soil is more concentrated. By this reason estimation of RSC is vital for suitability of irrigation and calculated with following equation (Eaton 1950):

$\mathrm{RSC}=\left(\mathrm{CO}_{3}^{-}+\mathrm{HCO}_{3}^{-}\right)-\left(\mathrm{Ca}^{2+}+\mathrm{Mg}^{2+}\right)$

where all ionic concentrations are expressed in meq/L. Calculated RSC values ranged from -13.37 to 3.76 and -3.30 to $2.30 \mathrm{meq} / \mathrm{L}$ in groundwater and surface water, respectively. About $56 \%$ and $80 \%$ of collected groundwater and surface water samples are under the safe limits, followed by $20 \%$ of water samples that are doubtful for irrigation and its illustration has been given in Table 8 .

Permeability index $(P I)$ is another important parameter to estimate the suitability of water for irrigation. Sodium, calcium, magnesium and bicarbonate contents were always influenced soil permeability, and it is defined by the following equation (Doneen 1964; Ragunath 1987):

$\mathrm{PI}=\frac{\mathrm{Na}^{+}+\sqrt{\mathrm{HCO}_{3}}}{\left(\mathrm{Ca}^{2+}+\mathrm{Mg}^{2+}+\mathrm{Na}^{+}\right)} \times 100$

where all the ions are expressed in meq/L. The computed analytical data explains that the $60 \%$ and $100 \%$ of the collected groundwater and surface water samples fall in class I and 37\% in class II, indicating that the groundwater is in good quality for irrigation purposes; only one water sample belongs to class III which is unsuitable for irrigation purposes (Fig. 19; Domenico and Schwartz 1990). 
Fig. 16 The piper diagram, graphically displaying the 30 water samples from the Mothkur region, Telangana State, South India

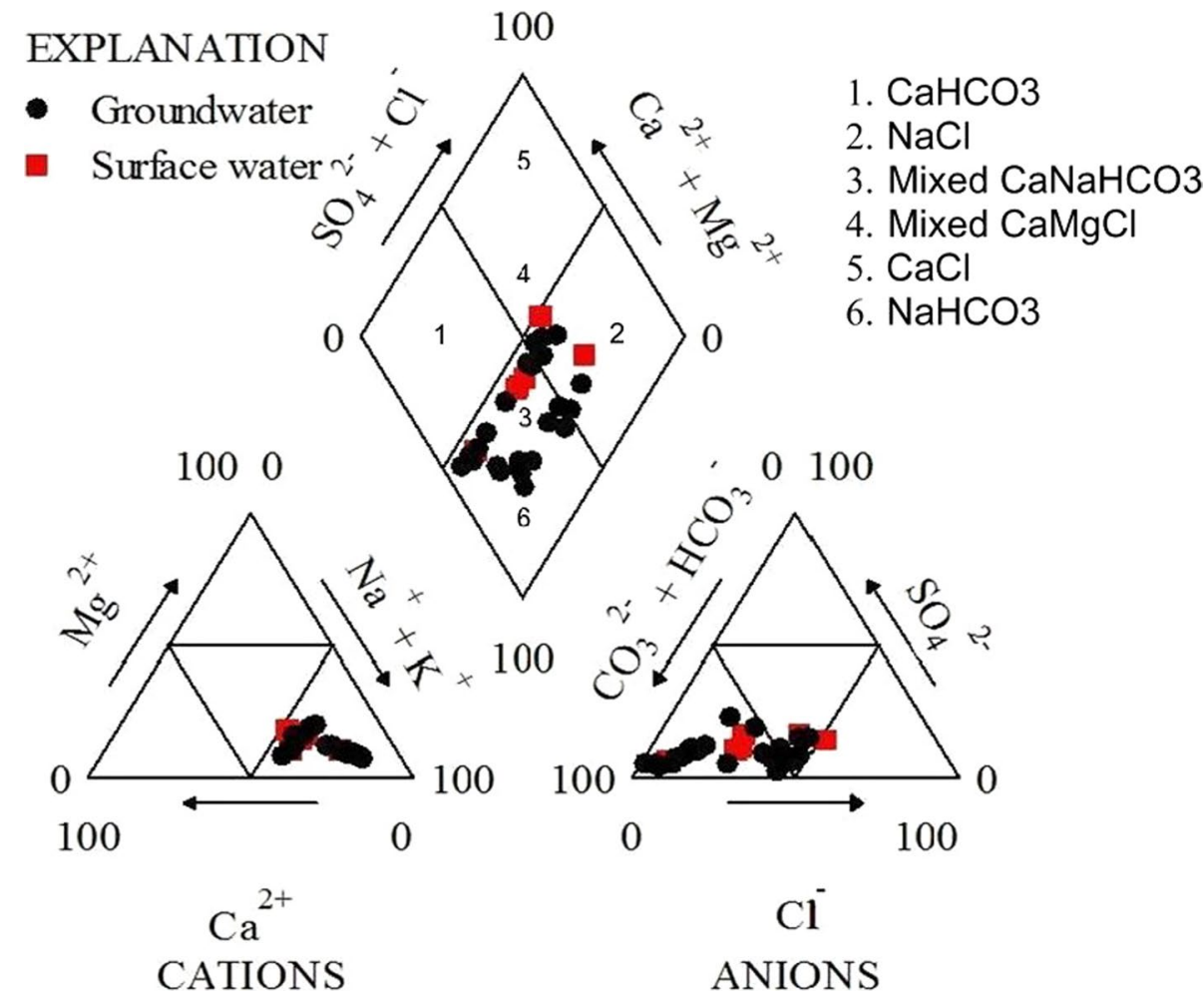

Table 8 Classification of water quality for irrigation on the basis of \% Na and RSC in the study region, Telangana State, South India

\begin{tabular}{|c|c|c|c|c|c|}
\hline Classification pattern & Range & Water type & Sample numbers & $\begin{array}{l}\% \text { of } \\
\text { ground- } \\
\text { water }\end{array}$ & $\begin{array}{l}\% \text { of } \\
\text { surface } \\
\text { water }\end{array}$ \\
\hline \multirow{5}{*}{$\begin{array}{l}\text { Per cent sodium }(\% \mathrm{Na})(\text { Wilcox } 1955) \\
(\mathrm{meq} / \mathrm{L})\end{array}$} & $<20$ & Excellent for irrigation & - & - & - \\
\hline & $20-40$ & Good for irrigation & - & - & - \\
\hline & $40-60$ & Permissible for irrigation & BH-1, BH-13 to BH-25, SW-1 to SW-5 & 56 & 100 \\
\hline & $60-80$ & Doubtful for irrigation & $\mathrm{BH}-2$ to $\mathrm{BH}-11$ & 44 & - \\
\hline & $>80$ & Unsuitable for irrigation & - & - & - \\
\hline \multirow[t]{3}{*}{$\begin{array}{l}\text { Residual sodium carbonate (RSC) (Rich- } \\
\text { ards } 1954)(\mathrm{meq} / \mathrm{L})\end{array}$} & $<1.25$ & Good for irrigation & $\begin{array}{l}\text { BH-1, BH-3, BH-4, BH-14 to BH-22, } \\
\text { BH-24, BH-25, SW-2 to SW-5 }\end{array}$ & 56 & 80 \\
\hline & $1.25-2.5$ & Doubtful for irrigation & $\begin{array}{l}\text { BH-5, BH-6, BH-7, BH-10, BH-23, } \\
\text { SW-1 }\end{array}$ & 20 & 20 \\
\hline & $>2.5$ & Unsuitable for irrigation & $\begin{array}{l}\text { BH-2, BH-8, BH-9, BH-11, BH-12, } \\
\text { ВH-13 }\end{array}$ & 24 & - \\
\hline
\end{tabular}

$S W$ surface water, $B H$ bore hole water/groundwater

\section{Conclusions}

The groundwater and surface water samples of the Mothkur region have been studied to assess the suitability for drinking and irrigation purposes. The analytical data were compared with WHO and BIS standards to know the suitability. The dominant constituents of water are as follows: $\mathrm{Na}^{+}>\mathrm{Ca}^{2+}>\mathrm{Mg}^{2+}>\mathrm{K}^{+}$for cation and $\mathrm{Cl}^{-}>\mathrm{HCO}_{3}^{-}>\mathrm{SO}_{4}^{2-}>\mathrm{F}^{-}$for anions. The results indicate that $\mathrm{Na}^{+}, \mathrm{Mg}^{2+}, \mathrm{Cl}^{-}$and $\mathrm{F}^{-}$concentrations are above maximum permissible limits recommended by World health organization (WHO) and Bureau of Indian standards (BIS) in the study region. The US salinity diagram reveals that $44 \%$ and $60 \%$ of the groundwater and surface water samples fall in 
Table 9 Zone classification of water quality for irrigation on the basis of EC and SAR

\begin{tabular}{|c|c|c|c|c|c|c|}
\hline Classification pattern & Zone range & Water quality & Zone explanation/property & Sample numbers & $\begin{array}{l}\% \text { of } \\
\text { ground- } \\
\text { water }\end{array}$ & $\begin{array}{l}\% \text { of } \\
\text { surface } \\
\text { water }\end{array}$ \\
\hline \multirow[t]{4}{*}{ SAR concentration (meq/L) } & $\mathrm{S} 1<10$ & Excellent & $\begin{array}{l}\text { Low-sodium water can be used } \\
\text { for irrigation on almost all } \\
\text { soils, with little danger of the } \\
\text { development of harmful levels } \\
\text { of exchangeable sodium }\end{array}$ & $\mathrm{BH}-1$ to $\mathrm{BH}-25, \mathrm{SW}-1$ to SW-5 & 100 & 100 \\
\hline & S2 10-18 & Good & $\begin{array}{l}\text { Medium-sodium water will } \\
\text { present an appreciate sodium } \\
\text { hazard in fine-textured soils, } \\
\text { especially poorly leached soils. } \\
\text { Such water may be used safely } \\
\text { on coarse-textured or organic } \\
\text { soils that have good perme- } \\
\text { ability }\end{array}$ & - & - & - \\
\hline & S3 18-26 & Permissible & $\begin{array}{l}\text { High-sodium water may produce } \\
\text { harmful levels of exchangeable } \\
\text { sodium in most soils and will } \\
\text { require a special soil manage- } \\
\text { ment like good drainage and } \\
\text { leaching, and addition of organic } \\
\text { matter }\end{array}$ & - & - & - \\
\hline & $\mathrm{S} 4>26$ & Unsuitable & $\begin{array}{l}\text { Very high sodium water is gener- } \\
\text { ally unsatisfactory for irrigation, } \\
\text { unless special action is taken, } \\
\text { such as addition of gypsum to } \\
\text { the soil }\end{array}$ & - & - & - \\
\hline \multirow[t]{4}{*}{ EC concentration $(\mu \mathrm{S} / \mathrm{cm})$} & $\mathrm{C} 1<250$ & Excellent & $\begin{array}{l}\text { Low-salinity water can be used for } \\
\text { irrigation of most crops on most } \\
\text { soils, with little likelihood of } \\
\text { soil salinity development. Some } \\
\text { leaching is required, but this } \\
\text { occurs under normal irrigation } \\
\text { practices, except in soils of } \\
\text { extremely low permeability }\end{array}$ & - & - & - \\
\hline & C2 250-750 & Good & $\begin{array}{l}\text { Medium-salinity water can be } \\
\text { used if a moderate amount } \\
\text { of leaching occurs. Crops of } \\
\text { moderate salt tolerance can be } \\
\text { irrigated with this water without } \\
\text { special practices for salinity } \\
\text { control }\end{array}$ & $\mathrm{BH}-15, \mathrm{BH}-23$ & 8 & - \\
\hline & C3 750-2250 & Permissible & $\begin{array}{l}\text { High-salinity water cannot be used } \\
\text { on soils of restricted drainage. } \\
\text { Even with adequate drainage, } \\
\text { special management for salinity } \\
\text { control may be required and } \\
\text { crops of good salt tolerance can } \\
\text { be selected }\end{array}$ & $\begin{array}{l}\text { SW-1, SW-3 to } 5, \text { BH-2 to BH-13, } \\
\text { BH-19 to BH-22, BH-24, } \\
\text { BH-25 }\end{array}$ & 72 & 80 \\
\hline & $\mathrm{C} 4>2250$ & Unsuitable & $\begin{array}{l}\text { Very high salinity water is not } \\
\text { suitable for irrigation under } \\
\text { ordinary conditions. It can be } \\
\text { used only on crops that are } \\
\text { very tolerant of salt and only if } \\
\text { special practices are followed, } \\
\text { including provision for a high } \\
\text { degree of adverse effects }\end{array}$ & $\begin{array}{l}\text { SW-2, BH-1, BH-6, BH-14, } \\
\text { BH-17, BH-18 }\end{array}$ & 20 & 20 \\
\hline
\end{tabular}

(US Salinity Laboratory Staff 1954)

$S W$ surface water, $B H$ bore hole water/groundwater 
Table 10 Criteria for water quality for irrigation following the (US Salinity Laboratory Staff 1954), in Mothkur region, Telangana State, South India

\begin{tabular}{|c|c|c|c|c|c|}
\hline Zone & Water type & Sample numbers & $\begin{array}{l}\% \text { of } \\
\text { ground- } \\
\text { water }\end{array}$ & $\begin{array}{l}\% \text { of } \\
\text { surface } \\
\text { water }\end{array}$ & Water quality \\
\hline C1S1 & Low salinity hazard and low sodium hazard & - & - & - & Good \\
\hline $\mathrm{C} 1 \mathrm{~S} 2$ & Low salinity hazard and medium sodium hazard & - & - & - & Moderate \\
\hline C1S3 & Low salinity hazard and high sodium hazard & - & - & - & Poor \\
\hline C1S4 & Low salinity hazard and very high sodium hazard & - & - & - & Very poor \\
\hline $\mathrm{C} 2 \mathrm{~S} 1$ & Medium salinity hazard and low sodium hazard & SW-2, SW-5 & - & 40 & Good \\
\hline $\mathrm{C} 2 \mathrm{~S} 2$ & $\begin{array}{l}\text { Medium salinity hazard and medium sodium } \\
\text { hazard }\end{array}$ & - & - & - & Moderate \\
\hline $\mathrm{C} 2 \mathrm{~S} 3$ & Medium salinity hazard and high sodium hazard & - & - & - & Poor \\
\hline $\mathrm{C} 2 \mathrm{~S} 4$ & $\begin{array}{l}\text { Medium salinity hazard and very high sodium } \\
\text { hazard }\end{array}$ & - & - & - & Very poor \\
\hline C3S1 & High salinity hazard and low sodium hazard & $\begin{array}{l}\text { SW-1, SW-3, SW-4, BH-7 to BH-13, BH-19, } \\
\text { BH-20, BH-23, BH-24, BH-25 }\end{array}$ & 44 & 60 & Moderate \\
\hline $\mathrm{C} 3 \mathrm{~S} 2$ & High salinity hazard and medium sodium hazard & $\begin{array}{l}\text { ВН-2, ВН-3, ВН-4, ВН-5, ВН-15, ВН-22, } \\
\text { ВН-19, ВН-6 }\end{array}$ & 32 & - & Moderate \\
\hline $\mathrm{C} 3 \mathrm{~S} 3$ & High salinity hazard and high sodium hazard & - & - & - & Poor \\
\hline C3S4 & $\begin{array}{l}\text { High salinity hazard and very high sodium } \\
\text { hazard }\end{array}$ & - & - & - & Very poor \\
\hline C4S1 & Very high salinity hazard and low sodium hazard & - & - & - & Very poor \\
\hline $\mathrm{C} 4 \mathrm{~S} 2$ & $\begin{array}{l}\text { Very high salinity hazard and medium sodium } \\
\text { hazard }\end{array}$ & ВН-14, ВН-16, ВН-17, ВН-21, ВН-18, ВН-1 & 24 & - & Very poor \\
\hline $\mathrm{C} 4 \mathrm{~S} 3$ & $\begin{array}{l}\text { Very high salinity hazard and high sodium } \\
\text { hazard }\end{array}$ & - & - & - & Very poor \\
\hline C4S4 & $\begin{array}{l}\text { Very high salinity hazard and very high sodium } \\
\text { hazard }\end{array}$ & - & - & - & Very poor \\
\hline
\end{tabular}

$S W$ surface water, $B H$ bore hole water/groundwater

Fig. 17 US salinity diagram for classification of irrigation waters (after Richards 1954), samples from the Mothkur region, Telangana State, South India

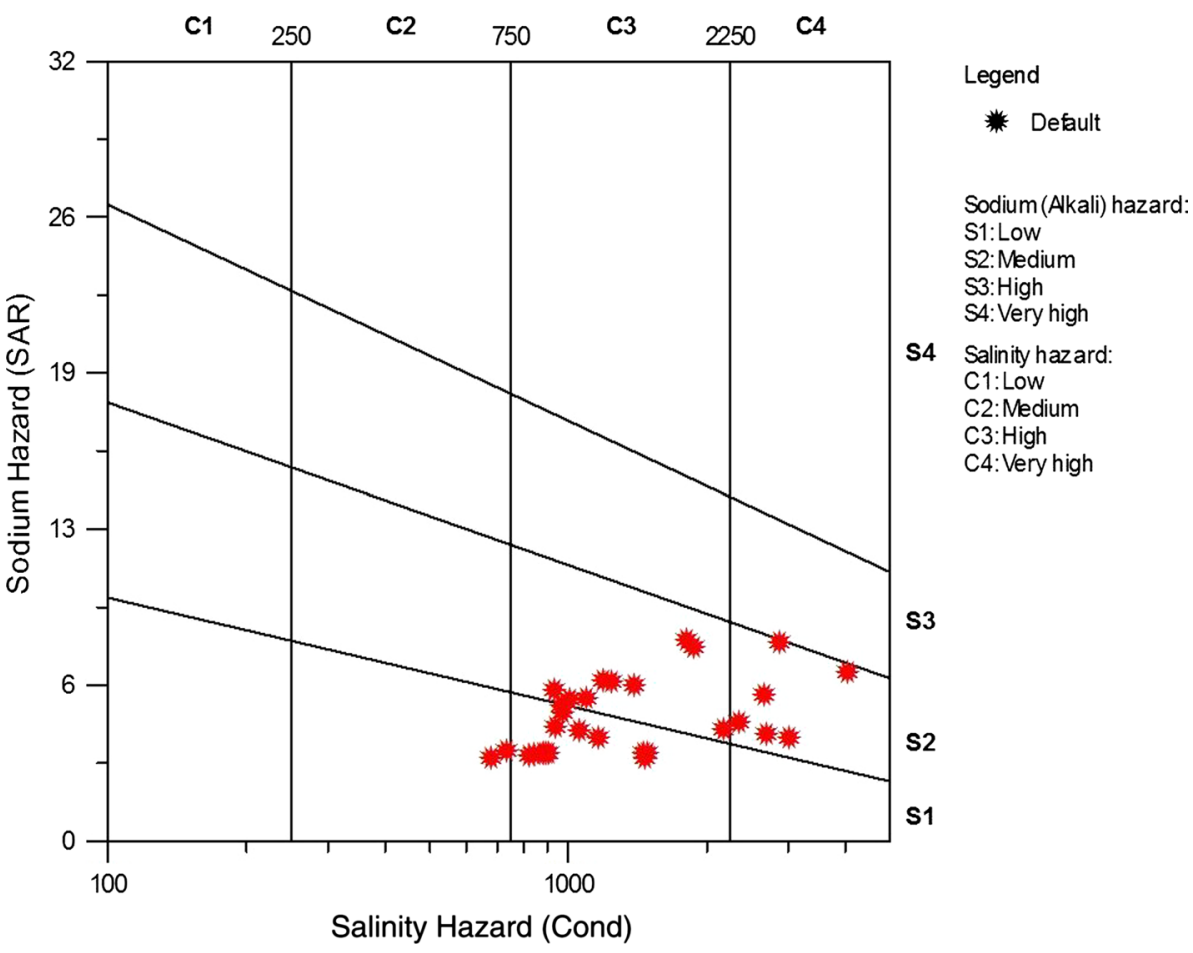




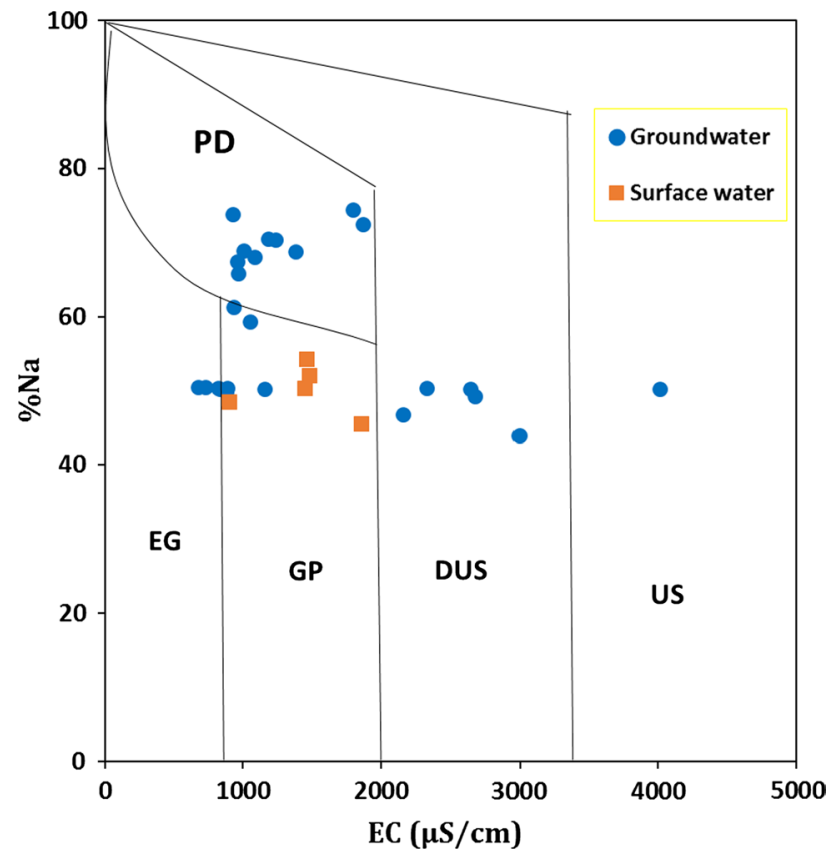

Fig. 18 Wilcox diagram for classification of water based on EC and $\% \mathrm{Na}$ (EG-excellent to good, GP-good to permissible, DUSdoubtful to unsuitable, PD-permissible to doubtful, US-unsuitable)

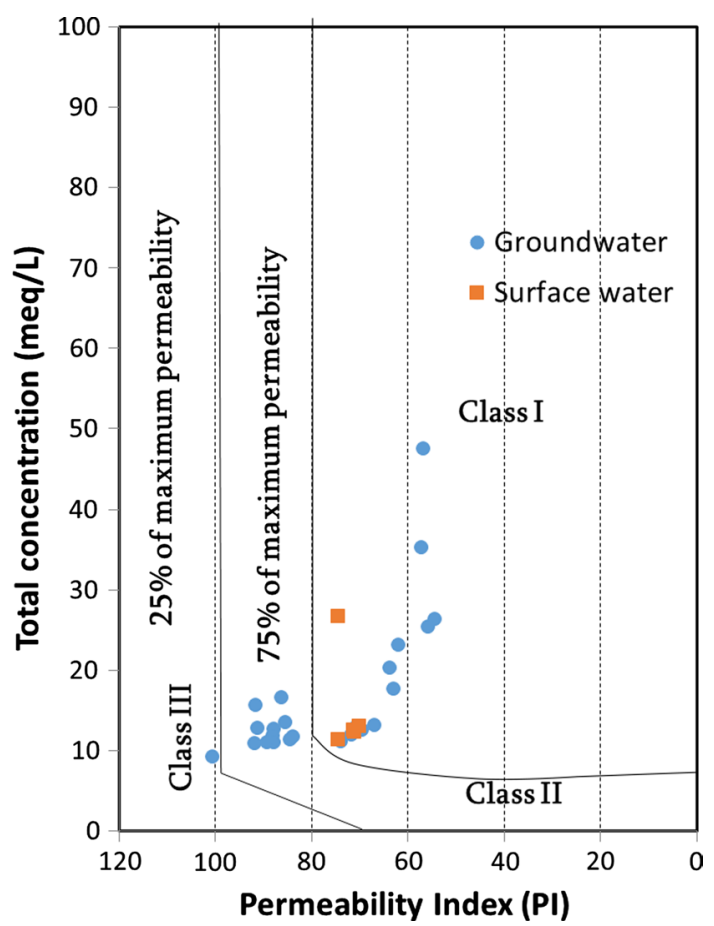

Fig. 19 Doneen (1964) classification of irrigation water quality based on the permeability index the category of $\mathrm{C} 3 \mathrm{~S} 1$ and $32 \%$ of groundwater samples fall in C3S2 and are useful for irrigation in almost all types of soils. Based on Wilcox classification, $36 \%$ of the groundwater samples are suitable for irrigation, $40 \%$ and $20 \%$ groundwater samples fall in permissible to doubtful and doubtful to unsuitable categories. Moreover, 56\% of groundwater and all surface water samples belong to permissible limits based on per cent sodium for irrigation utility. Based on the classification of irrigation water according to residual sodium carbonate values, $56 \%$ of the groundwater and all surface water samples belong to good for irrigation purposes. The permeability index indicates that the water of the study area is of good quality for irrigation utility.

Acknowledgements Financial support of this research work by the Department of Science and Technology (DST)—Science and Engineering Research Board (SERB) Government of India, New Delhi, under the Start-Up Research Grant (Young Scientists) project (SR/FTP/ ES-13/2013) is gratefully acknowledged by the second author (Narsimha Adimalla). The authors are highly thankful to anonymous reviewer for comprehensively reviewing the manuscript and helpful suggestions. We extend our sincere thanks to Prof. V. Sudarshan (UGC Basic Science Research Faculty Fellow, Department of Applied Geochemistry) for his constant support and encouragement throughout the research work.

Open Access This article is distributed under the terms of the Creative Commons Attribution 4.0 International License (http://creativeco mmons.org/licenses/by/4.0/), which permits unrestricted use, distribution, and reproduction in any medium, provided you give appropriate credit to the original author(s) and the source, provide a link to the Creative Commons license, and indicate if changes were made.

\section{References}

Adimalla N, Venkatayogi S (2017) Mechanism of fluoride enrichment in groundwater of hard rock aquifers in Medak, Telangana State, South India. Environ Earth Sci 76:45. https://doi.org/10.1007/ s12665-016-6362-2

Adimalla N, Venkatayogi S (2018) Geochemical characterization and evaluation of groundwater suitability for domestic and agricultural utility in semi-arid region of Basara, Telangana State, South India. Appl Water Sci 8(1):44. https://doi.org/10.1007/s 1320 1-018-0682-1

Adimalla N, Li P, Venkatayogi S (2018a) Hydrogeochemical evaluation of groundwater quality for drinking and irrigation purposes and integrated interpretation with water quality index studies. Environ Process 5(2):363-383. https://doi.org/10.1007/s4071 0-018-0297-4

Adimalla N, Li P, Qian H (2018b) Evaluation of groundwater contamination for fluoride and nitrate in semi-arid region of Nirmal Province, South India: a special emphasis on human health risk assessment (HHRA). Hum Ecol Risk Assess Int J. https://doi. org/10.1080/10807039.2018.1460579

Adimalla N, Vasa SK, Li P (2018c) Evaluation of groundwater quality, Peddavagu in Central Telangana (PCT), South India: an insight of controlling factors of fluoride enrichment. Model Earth Syst Environ 4(2):841-852. https://doi.org/10.1007/s40808-018-0443-z

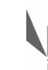

$$
\checkmark
$$


Aghazadeh N, Mogaddam AA (2011) Investigation of hydrochemical characteristics of groundwater in the Harzandat aquifer, Northwest of Iran. Environ Monit Assess 176:183-195

Alam M, Rais S, Aslam M (2012) Hydrochemical investigation and quality assessment of ground water in rural areas of Delhi. India Environ Earth Sci 66:97-100

Alexakis Dimitris (2011) Assessment of water quality in the Messolonghi-Etoliko and Neochorio region (West Greece) using hydrochemical and statistical analysis methods. Environ Monit Assess 2011(182):397-413

Alexakis D, Tsakiris G (2010) Drought impacts on karstic spring annual water potential. Application on Almyros (Heraklion Crete) brackish spring. Desalin. Water Treat. 16:1-9

Amiri V, Sohrabi N, Dadgar MA (2015) Evaluation of groundwater chemistry and its suitability for drinking and agricultural uses in the Lenjanat plain, central Iran. Environ Earth Sci 74:6163-6176

APHA (1995) Standard methods for the examination of water and wastewater, 19th edn. American Public Association, Washington, DC

Appelo CAJ, Postma D (2005) Geochemistry, groundwater and pollution, 2nd edn. Balkema, Rotterdam

Ayoob S, Gupta AK (2006) Fluoride in drinking water: a review on the status and stress effects. Crit Rev Environ Sci Technol 36:433-487

BIS (2003) Drinking water-specification. Bureau of Indian standards, New Delhi IS: 10500

Brown E, Skougstand MW, Fishman MJ (1970) Methods for collection and analyses of water samples for dissolved minerals and gases. Techniques of Water Resources Investigation of the US Geological Survey 5

Choi BY, Yun ST, Yu SY, Lee PK, Park SS, Chae GT et al (2005) Hydrochemistry of urban groundwater in Seoul, South Korea: effect of landuse and pollutant recharge. Environ Geol 48:979-990

Deepali M, Malpe DB, Zade AB (2012) Major ion chemistry of shallow groundwater of a fast growing city of Central India. Environ Monit Assess 184:2405-2418

Domenico PA, Schwartz FW (1990) Physical and chemical hydrogeology. Wiley, New York, pp 410-420

Doneen LD (1964) Notes on water quality in agriculture. Published as a water science and engineering paper, 4001, Department of water science and engineering, University of California

Drever JI (1997) The geochemistry of natural waters. Prentice-Hill, New York, p 379

Eaton FM (1950) Significance of carbonates in irrigation waters. Soil Sci 39:123-133

Fetter CW (1990) Applied hydrogeology. CBS Publishers and Distributors, New Delhi

Freeze RA, Cherry JA (1979) Groundwater. Prentice-Hall, Englewood Cliffs

Ghazaryan K, Chen Y (2016) Hydrochemical assessment of surface water for irrigation purposes and its influence on soil salinity in Tikanlik oasis, China. Environ Earth Sci 75:383

Hajizadeh Namaghi H, Karami GH, Saadat S (2011) A study on chemical properties of groundwater and soil in ophiolitic rocks in Firuzabad, east of Shahrood, Iran: with emphasis to heavy metal contamination. Environ Monit Assess 174:573-583

Handa BK (1975) Geochemistry and genesis of fluoride containing groundwater in India. Groundwater 13:275-281

He J, Ma J, Zhao W, Sun S (2015) Groundwater evolution and recharge determination of the Quaternary aquifer in the Shule River basin, Northwest China. Hydrogeol J 23:1745-1759

Hem JD (1985) Study and interpretation of the chemical characteristics of natural water. USGS Water Supply Pap 2254:117-120

Hem JD (1991) Study and interpretation of the chemical characteristics of natural water: USGS Professional Paper Book 2254. Scientific Publishers, Jodhpur
Hounslow AW (1995) Water quality data: analysis and interpretation. CRC Press LLC, Lewis publishers, Boca Raton

International Institute for Environment and Development (IIED) (2002) Breaking new ground: mining, minerals and sustainable development. Earthscan Publication, London

Jankowski J, Acworth RI (1997) Impact of debris flow deposits on hydrogeochemical process and the development of dry land salinity in the Yass River catchment, New South Wales, Australia. Hydrogeol J 5:71-88

Jeevanandam M, Kannan R, Srinivasalu S, Rammohan V (2006) Hydrogeochemistry and groundwater quality assessment of lower part of the Ponnaiyar River Basin, Cuddalore district, South India. Environ Monit Assess 132(1):263-274

Karanth KR (1987) Ground water assessment development and management. Tata McGraw-Hill, Noida, p 720

Karanth KR (1989) Groundwater assessment, development and management. Tata McGraw-Hill Publishing Company Ltd, New Delhi

Kaur T, Bhardwaj Renu, Arora Saroj (2016) Assessment of groundwater quality for drinking and irrigation purposes using hydrochemical studies in Malwa region, southwestern part of Punjab. Appl Water Sci, India. https://doi.org/10.1007/s13201-016-0476-2

Kelly WR (1997) Heterogeneities in ground-water geochemistry in a sand aquifer beneath an irrigated field. J Hydrol 19:154-176

Koritnig S (1951) Ein Beitrag zur Geochemie des Fluor (A contribution to the geochemisty of fluorine). Geochim Cosmochim Acta 1:89

Kudoda AM, Abdalla OA (2015) Hydrochemical characterization of the main aquifers in Khartoum, the capital city of Sudan. Environ Earth Sci 74:4771-4786

Kundu N, Panigrahi MK, Tripathy S, Munshi S, Powell MA, Hart BR (2001) Geochemical appraisal of fluoride contamination of groundwater in the Nayagarh District of Orrissa. Indian Environ. Geol 41:451-460

Li P, Wu J, Qian H (2012) Assessment of groundwater quality for irrigation purposes and identification of hydrogeochemical evolution mechanisms in Pengyang County, China. Environ Earth Sci 69:2211-2225

Li P, Wu J, Qian H (2014) Hydrogeochemistry and Quality assessment of shallow groundwater in the southern part of the Yellow River alluvial plain (Zhongwei section), Northwest China. Earth Sci Res J 18(1):27-38. https://doi.org/10.15446/esrj.v18n1.34048

Li P, Tian R, Xue C, Wu J (2017a) Progress, opportunities and key fields for groundwater quality research under the impacts of human activities in China with a special focus on western China. Environ Sci Pollut Res 24(15):13224-13234. https://doi. org/10.1007/s11356-017-8753-7

Li P, He S, He X, Tian R (2017b) Seasonal hydrochemical characterization and groundwater quality delineation based on matter element extension analysis in a paper wastewater irrigation area, Northwest China. Expo Health. https://doi.org/10.1007/s1240 3-017-0258-6

Loizidou M, Kapetanios EG (1993) Effect of leachate from landfills on underground water quality. Sci Total Environ 128:69-81

Matthess G (1982) The properties of groundwater. Wiley, New York

Meybeck M (1987) Global chemical weathering of surficial rocks estimated from river dissolved loads. Am J Sci 287(5):401-428

Murkute YA (2014) Hydrogeochemical characterization and quality assessment of groundwater around Umrer coal mine area Nagpur District, Maharashtra, India. Environ Earth Sci 72:4059-4073

Narsimha A (2012) Geochemistry of groundwater Basara area, Adilabad district Andhra Pradesh. Ph.D. Thesis, Osmania University

Narsimha A (2018) Elevated fluoride concentration levels in rural villages of Siddipet, Telangana State, South India. Data Brief 16:693-699

Narsimha A, Sudarshan V (2013) Hydrogeochemistry of groundwater in Basara area, Adilabad District, Andhra Pradesh, India. J Appl Geochem 15(2):224-237 
Narsimha A, Sudarshan V (2017a) Contamination of fluoride in groundwater and its effect on human health: a case study in hard rock aquifers of Siddipet, Telangana State, India. Appl Water Sci 7:2501-2512. https://doi.org/10.1007/s13201-016-0441-0

Narsimha and Sudarshan (2017b) Assessment of fluoride contamination in groundwater from Basara, Adilabad District, Telangana State, India. Appl Water Sci 7:2717-2725. https://doi. org/10.1007/s13201-016-0489-x

Narsimha A, Rajitha S (2018) Spatial distribution and seasonal variation in fluoride enrichment in groundwater and its associated human health risk assessment in Telangana State, South India. Hum Ecol Risk Assess Int J 24(8):2119-2132

Narsimha A, Sudarshan V, Swathi P (2013a) Groundwater and its assessment for irrigation purpose in Hanmakonda Area, Warangal District, Andhra Pradesh, India. Int J Res Chem Environ 3(2):196-200

Narsimha A, Sudarshan V, Srinivasulu P, Anitha N, Parameshwar V (2013b) An integrated approach to assess the quality of groundwater in part of Cheralapally area, Rangareddy District, Andhra Pradesh, India. Adv Appl Sci Res 4(1):244-253

Narsimha A, Venkatayogi S, Geeta S (2018) Hydrogeochemical data on groundwater quality with special emphasis on fluoride enrichment in Munneru river basin (MRB), Telangana State, South India. Data Brief 17:339-346

Panaskar DB, Wagh VM, Muley AA, Mukate SV, Pawar RS, Aamalawar ML (2016) Evaluating groundwater suitability for the domestic, irrigation, and industrial purposes in Nanded Tehsil, Maharashtra, India, using GIS and statistics. Arab J Geosci 9:615. https ://doi.org/10.1007/s12517-016-2641-1

Piper AM (1944) A graphical procedure in the geochemical interpretation of water analysis. Am Geophys Union Trans 25:914-928

Qian Cheng, Xiong Wu, Wen-Ping Mu, Rui-Zhi Fu, Zhu Ge, Wang Zhuo-Ran, Wang Dan-dan (2016) Hydrogeochemical characterization and suitability assessment of groundwater in an agropastoral area, Ordos Basin, NW China. Environ Earth Sci 75:1356

Ragunath HM (1987) Groundwater. Wiley Eastern, New Delhi, p 563

Raju KCB (1998) Importance of recharging depleted aquifers: state of the art of artificial recharge in India. J Geol Soc India 5:429-454

Raju Nandimandalam Janardhana, Shukla UK, Ram Prahlad (2011) Hydrogeochemistry for the assessment of groundwater quality in Varanasi: a fast-urbanizing center in Uttar Pradesh, India. Environ Monit Assess 173:279-300

Ravikumar P, Venkatesharaju K, Prakash KL, Somashekar RK (2012) Geochemistry of groundwater and groundwater prospects evaluation, Anekal Taluk, Bangalore Urban District, Karnataka, India. Environ Monit Assess. https://doi.org/10.1007/s1066 1-010-1721-z

Richards LA (1954) Diagnosis and improvement of saline alkali soils: agriculture, vol 160, Handbook 60. U.S. Department of Agriculture, Washinghton DC

Salem ZE, Atwia MG, El-Horiny MM (2015) Hydrogeochemical analysis and evaluation of groundwater in the reclaimed small basin of Abu Mina, Egypt. Hydrogeol J 23:1781-1797

Sappa G, Ergul S, Ferranti F, Sweya LN, Luciani G (2015) Effects of seasonal change and seawater intrusion on water quality for drinking and irrigation purposes, in coastal aquifers of Dares Salaam, Tanzania. J Afr Earth Sc 105:64-84

Sawyer CN, McCarty PL (1967) Chemistry for sanitary engineers, 2nd edn. McGraw-Hill, New York

Sethy SN, Syed TH, Kumar A, Sinha D (2016) Hydrogeochemical characterization and quality assessment of groundwater in parts of Southern Gangetic Plain. Environ Earth Sci 75:232

Sheikh MA, Azad C, Mukherjee S, Rina Kumari (2017) An assessment of groundwater salinization in Haryana state in India using hydrochemical tools in association with GIS. Environ Earth Sci 76:465. https://doi.org/10.1007/s12665-017-6789-0

Soltan ME (1998) Characterization, classification, and evaluation of some groundwater samples in upper Egypt. Chemosphere 37:735-745

Soltan ME (1999) Evaluation of groundwater quality in Dakhla Oasis (Egyptian Western Desert). Environ Monit Assess 57:157-168

Srinivas Y, Hudson Oliver D, Stanley Raj A, Chandrasekar N (2013) Evaluation of groundwater quality in and around Nagercoil town, Tamilnadu, India: an integrated geochemical and GIS approach. Appl Water Sci 3:631-651

Stallard RF, Edmond JM (1983) Geochemistry of Amazon, the influence of geology and weathering environment on the dissolved load. J Geophys Res 88:9671-9688

Subba Rao N, Subrahmanyam A, Ravi Kumar S, Srinivasulu N, Babu Rao G, Surya Rao P, Venkatram Reddy G (2012) Geochemistry and quality of groundwater of Gummanampadu sub-basin, Guntur District, Andhra Pradesh, India. Environ Earth Sci. https://doi. org/10.1007/s12665-012-1590-6

Subramani T, Elango L, Damodarasamy SR (2005) Groundwater quality and its suitability for drinking and agricultural use in Chitar River Basin, Tamilnadu, India. Environ Geol 47:1099-1110

Sudarshan V, Geeta S, Narsimha A, Shankar S, Ravi Kumar A (2014) Fluoride distribution in the groundwater of Narsampet Area, Warangal District, Andhra Pradesh, India. Int J Earth Sci Eng 7(1):203-212

Sudhakar A, Narsimha A (2013) Suitability and assessment of groundwater for irrigation purpose: a case study of Kushaiguda area, Ranga Reddy district, Andhra Pradesh, India. Adv Appl Sci Res 4(6):75-81

Tamma RG, Srinivasa RY, Mahesh J, Surinaidu L, Dhakate R, Gurunadha RVVS, Durga PM (2015) Hydrochemical assessment of groundwater in alluvial aquifer region, Jalandhar District, Punjab, India. Environ Earth Sci 73:8145-8153

Thakur T, Rishi MS, Naik PK, Sharma P (2016) Elucidating hydrochemical properties of groundwater for drinking and agriculture in parts of Punjab, India. Environ Earth Sci 75:467

Todd DK (1980) Groundwater hydrology, 2nd edn. Wiley, New York, p 535

USSL (1954) Diagnosis and improvement of salinity and alkaline soil. USDA Hand Book no. 60, Washington

Wang H, Jiang X-W, Wan L, Han G, Guo H (2015) Hydrogeochemical characterization of groundwater flow systems in the discharge area of a river basin. J Hydrol 527:433-441

Wenzel WW, Blum WEH (1992) Fluoride speciation and mobility in fluoride contaminated soils and minerals. Soil Sci 153:357-364

WHO (1997) Guideline for drinking water quality. Recommendations, vol 1, 2nd edn. WHO, Geneva

Wilcox LV (1955) Classification and use of irrigation water. USDA, Circular, Washington, p 969

Williams DD, Williams NE, Cao Y (1999) Road salt contamination of groundwater in a major metropolitan area and development of a biological index to monitor its impacts. Water Res 34:127-138

Younger PL (2007) Groundwater in the environment: an introduction. Blackwell Publishing, Oxford

Publisher's Note Springer Nature remains neutral with regard to jurisdictional claims in published maps and institutional affiliations. 